\title{
THE UNDERPRIVILEGED PROFESSION: THE CASE FOR SUPREME COURT RECOGNITION OF THE JOURNALIST'S PRIVILEGE
}

\author{
JEFFREY S. NESTLER ${ }^{\dagger}$ \\ [T] he public has a right to every man's evidence, a maxim which in its proper \\ sense cannot be denied. ${ }^{1}$ \\ -Lord Chancellor Hardwicke, during debate in Parliament, 1742 \\ [Edmund] Burke said there were Three Estates in Parliament; but in the Report- \\ ers' Gallery yonder, there sat a Fourth Estate more important far than they all. \\ It is not a figure of speech, or a witty saying; it is a literal fact,-very momentous \\ to us in these times. . . Whoever can speak, speaking now to the whole nation, \\ becomes a power, a branch of government, with inalienable weight in law-making, \\ in all acts of authority. ${ }^{2}$
}

-Thomas Carlyle, 1840

On July 6, 2005, Pulitzer Prize-winning New York Times reporter Judith Miller was jailed for refusing to disclose the identity of a confi-

\footnotetext{
† B.A. 2003, George Washington University; J.D. Candidate 2006, University of Pennsylvania Law School. I am deeply indebted to Professors Ed Baker and Catherine Struve for their helpful suggestions on earlier drafts of this Comment, and especially to Professor Baker for his insightful classes on the First Amendment and media policy. Many thanks to Rachel Brodin, Don Conklin, and Abby Wright for their countless hours spent editing the Comment and for putting up with the high demands of a nitpicky fellow editor. Most importantly, as with all achievements in my life, writing this Comment would not have been possible without the love and encouragement of my parents, Barbara and Ian, and my brothers, Matt and Eric. Though Emily Cohen might be surprised to hear this, I willingly accept full responsibility for any errors.

An earlier draft of this Comment won first place in the American Constitution Society's 2005 National Student Writing Competition.

${ }^{1} 8$ WigMORE ON EVIDENCE $\$ 2192$, at 71 (John T. McNaughton ed., 1961) (citing 12 PARL. HIST. ENG. (1742) 643, 693). This maxim has also long been present in the American legal system: "It is . . beyond controversy that one of the duties which the citizen owes to his government is to support the administration of justice by attending its courts and giving his testimony whenever he is properly summoned." Blackmer v. United States, 284 U.S. 421, 438 (1932) (Hughes, C.J.).

${ }^{2}$ Thomas Carlyle, ON Heroes, Hero-Worship, \& The Heroic in History 141 (Michael K. Goldberg et al. eds., 1993) (1840).
} 
dential source to a federal grand jury, ${ }^{3}$ making her one of a number of journalists imprisoned recently ${ }^{4}$ for adhering to the canons of their profession. $^{5}$ When prominent members of the media are jailed for adhering to principles that have long been an integral part of investigative reporting, it raises a question about the relationship between our judicial system and our democratic system of governance. Should the state's interest in mandating compliance with the rule of law outweigh the press's role as a Fourth Estate and check on the power of government?

This conflict between the freedom of the press and the needs of the judiciary has been present since colonial times. ${ }^{6}$ While the press seeks to gather and disseminate information, free from government intervention, the judicial system employs all possible means to find the truth. Only on rare occasions do we prevent the judiciary from obtaining the evidence it seeks on its truth-finding mission, and on these occasions the countervailing need is always that of a higher societal interest.

The constitutional roles of the press and the judiciary are at odds when a court issues a subpoena to a journalist, and this centuries-old at A1.

${ }^{3}$ Adam Liptak, Reporter Jailed After Refusing to Name Source, N.Y. TIMES, July 7, 2005,

${ }^{4}$ See Reporter's Comm. for Freedom of the Press, Paying the Price: A Recent Census of Reporters Jailed or Fined for Refusing to Testify, http://www.rcfp.org/jail.html (last visited Sept. 20, 2005) (listing the reporters who have been jailed over the past twenty years for refusing to testify).

${ }^{5}$ See Am. Soc'y of Newspaper Editors, Statement of Principles, art. VI (1975), available at http:/ / www.asne.org/index.cfm?id=888 (last visited Sept. 20, 2005) ("Pledges of confidentiality to news sources must be honored at all costs ...."). The Statement of Principles was originally adopted in 1922 as the Canons of Journalism. Id.

Bob Woodward, in his book about the Watergate scandal and "Deep Throat" Mark Felt, writes that promises of confidentiality played a crucial role in bringing the scandal to public attention: "There needed to be a model out there where people could come forward or speak when contacted, knowing they would be protected. It was a matter of my work, a matter of honor.” BOB WOODWARD, THE SECRET MAN 185 (2005).

${ }^{6}$ See Julie M. Zampa, Case Note, Journalist's Privilege: When Deprivation is a Benefit, 108 YALE L.J. 1449, 1449 (1999) ("Debate over the issue of a journalist's privilege not to disclose information and source identities to the courts predates the United States Constitution.”). Indeed, Benjamin Franklin and John Peter Zenger had run-ins with situations analogous to those raised by today's journalist's privilege. See MAURICE VAN GerPen, Privileged COMmunication ANd the PRESS: THE Citizen's Right to KNOW VERSUS THE LAW'S Right TO CONFIDENTIAL NEWS SOURCE EVIDENCE 5-6 (1979) (detailing Franklin's and Zenger's cases). 
tension has come to a head. ${ }^{7}$ The circumstances surrounding Judith Miller's jailing ${ }^{8}$ demonstrate the compelling need for the Supreme Court to recognize a journalist's privilege.

This Comment maintains that the need of the press to keep certain confidences is one of the few instances involving societal interests of greater import than the judiciary's search for the truth. Therefore, journalists should have a privilege, grounded in the common law and derived from the First Amendment, to refuse to answer subpoenas issued by judicial authorities. Further, the Supreme Court, under the authority vested in the judiciary by Federal Rule of Evidence 501, should be the entity that recognizes the privilege.

The state of the law in this area has changed drastically since 1972 when the Supreme Court decided in Branzburg v. Hayes ${ }^{9}$ that journalists, like other citizens, have a duty to provide testimony to grand juries. Almost every state and federal circuit now provides at least some type of statutory, common law, or constitutional protection for journalists. ${ }^{10}$ In addition, the need today for the privilege is even more urgent than it was thirty years ago.

The area of journalist's privilege law is necessarily large, and this Comment will not attempt to explore every facet. ${ }^{11}$ Instead, the Comment will focus on the jurisprudence and theory underlying the

${ }^{7}$ See In re Grand Jury Subpoena, Judith Miller, 397 F.3d 964, 1003 (D.C. Cir.) (Tatel, J., concurring) (noting that the debate over a privilege for journalists "[r]epresent[s] two equally fundamental principles-rule of law and free speech"), cert. denied, 125 S. Ct. 2977 (2005); STEPHEN BATES, THE REPORTER's PRIVILEGE, THEN AND NOW 14 (2000) (noting that both sides-prosecutors and journalists-see themselves as "exercising constitutional authority to serve the public interest. . . . The prosecutor thinks he is doing the people's business by issuing a subpoena; the journalist thinks he is doing the people's business by refusing to comply"); VAN GERPEN, supra note 6 , at 3 ("In a constitutional democracy there are at least two principles that are assumed. One is that the public has the right to know what is happening in the political system. The other is that the public through its prosecutors and defense counselors has the right to everyman's evidence.").

${ }^{8}$ For a description of the circumstances leading to Miller's jailing, see Judith Miller, 397 F.3d at 965-69; Liptak, supra note 3, at A1; Lorne Manly \& Adam Liptak, At Leak Inquiry's Center, a Circumspect Columnist, N.Y. TIMES, Dec. 31, 2004, at A18; REPORTER's COMM. FOR FREEDOM OF THE PRESS, SPECIAL REPORT: REPORTERS AND FEDERAL SUBPOENAS (July 7, 2005), http://www.rcfp.org/shields_and_subpoenas.html (keeping an up-to-date account of actions in the case and useful related links). For a quick (and opinionated) background of the case, see Hendrik Hertzberg, Comment (Editorial), The Matt and Judy Show, New YORKER, May 9, 2005, at 27.

${ }^{9} 408$ U.S. 665 (1972). See infra Part II.A for a discussion of Branzburg.

${ }^{10}$ See infra Part II.B (giving each state's stance on the issue); infra Part II.A (giving each circuit's stance on the issue).

${ }^{11}$ See infra Part I.C for a discussion of the contours of the privilege. 
journalist's privilege and how the judicial and media arenas have significantly changed since Branzburg was decided. It will then argue that the need for uniformity in the field is overwhelming, and that the best means to this end is Supreme Court recognition of a privilege for journalists, grounded in Federal Rule of Evidence 501.

Part I explores the background of the controversy, relevant First Amendment theory, and issues associated with testimonial privileges. Part II finds support for a journalist's privilege in federal case law, state shield laws and court decisions, and fellow common law jurisdictions' actions. Part III argues on four separate grounds why a privilege for journalists is necessary in today's media and legal atmosphere. Part IV analyzes why judges are traditionally opposed to the creation of a journalist's privilege and focuses specifically on the Supreme Court's antagonism toward the issue in Branzburg. Finally, Part V makes the case for Supreme Court recognition of the privilege under Federal Rule of Evidence 501.

\section{BACKGROUND}

\section{A. Theory}

The phrase "freedom of the press"-regardless of the particular brand of First Amendment jurisprudence to which one subscribescan support the creation of a privilege protecting reporters from having to reveal the nature of confidential information they received from sources who wished to remain anonymous.

Inevitably, much of the debate surrounding a potential journalist's privilege centers on the conception of "freedom of the press" as embodied in the First Amendment. ${ }^{12}$ Up until at least the early twentieth

${ }^{12}$ This Comment argues that the Supreme Court should recognize a privilege for journalists grounded in the common law (as prescribed by FED. R. EVID. 501). However, the subsequent discussion of the First Amendment is relevant for three important reasons: first, the First Amendment plays a large role in prescribing the role of the press as a check on government power in our democratic system of government; second, a prospective journalist's privilege has until recently been discussed purely in constitutional terms; and third, the constitutional approach has had a significant impact on the common law in this area. Indeed, the constitutional and common law approaches to the journalist's privilege have been confused almost to the point where they are inseparable. See In re Grand Jury Subpoena, Judith Miller, 397 F.3d 964, 977 (D.C. Cir.) (Sentelle, J., concurring) ("[T] he Branzburg Court repeatedly discussed the [journalist's] privilege question in common law terms as well as constitutional."), cert. denied, 125 S. Ct. 2977 (2005); Lawrence J. Mullen, Comment, Developments in the News Media 
century, the First Amendment's protection of "freedom of the press" and "freedom of speech" was thought by most commentators to be identical. $^{13}$ Professor Melville Nimmer suggests that the Framers included both phrases in the Amendment simply to ensure protection of all types of expression, both written and oral. ${ }^{14}$

If "freedom of the press" means nothing more than "freedom of written speech," then the constitutional argument for special privileges for journalists in court proceedings is indeed weak. Ordinary citizens are required to give testimony, and journalists cannot hide behind their profession to shirk their responsibility. If, instead, "freedom of the press" has a meaning separate from "freedom of speech"-say, "freedom of the media," or "freedom of newspapers, broadcasters, etc." - then journalists should arguably be afforded at least some protection in court proceedings.

Privilege: The Qualified Constitutional Approach Becoming Common Law, 33 ME. L. REv. 401, 406 (1981) (arguing that courts have begun to merge the constitutional and common law arguments for a journalist's privilege, leading to what the authors of Rule 501 envisioned: a common law privilege developing in the courts). In this respect, a federal common law journalist's privilege resembles what Professor Monaghan termed "constitutional common law," Henry P. Monaghan, The Supreme Court, 1974 TermForeword: Constitutional Common Law, 89 HARV. L. REV. 1, 26 (1975), and has been the subject of spirited academic debate. See, e.g., Richard H. FALlon, JR. ET AL., HART AND WeChSLER's The FEDERAL COURTS AND THE FEDERAL SySTEM 823-24 (5th ed. 2003) (outlining Monaghan's proposal and challenges to it); Thomas S. Schrock \& Robert C. Welch, Reconsidering the Constitutional Common Law, 91 HARV. L. REv. 1117, 1126 (1978) (criticizing Monaghan's argument and suggesting an alternative theory of judicial review); Kevin McNamee, Comment, Do As I Say and Not As I Do: Dickerson, Constitutional Common Law, and the Imperial Supreme Court, 28 FORDHAM URB. L.J. 1239, 1245 (2001) (suggesting limits on the constitutional common law to avoid infringing on federalism and separation of powers).

Therefore, because the First Amendment heavily informs the common law in this area, the argument developed in this Comment, though grounded in the common law, necessarily invokes First Amendment principles and language.

${ }^{13}$ See David A. Anderson, The Origins of the Press Clause, 30 UCLA L. REV. 455, 456 (1983) ("Through most of our history ... the terms freedom of speech and freedom of press have been used more or less interchangeably."); Anthony L. Fargo, Tell Me No Secrets: The Journalist's Privilege for Nonconfidential Information 69 (2000) (unpublished Ph.D. dissertation, University of Florida) (on file with the University of Pennsylvania Law Review) ("There was no evidence through the first half of the nineteenth century that the Framers meant anything more by 'the freedom of the press' than that individuals' ability to express their sentiments in writing should be free.").

${ }^{14}$ See Melville B. Nimmer, Introduction-Is Freedom of the Press a Redundancy: What Does It Add to Freedom of Speech?, 26 HASTINGS L.J. 639, 639 (1975) (“[T] he reference to 'speech' might [have] been construed to protect only oral expression, so . . the reference to the 'press' was added in order to explicitly protect written expression."). 


\section{What Did "Freedom of the Press" Mean?}

Most early commentators equated "freedom of the press" with speech. Blackstone was adamant that the press deserved no special protection, and in fact argued that government should have the power to regulate the press. ${ }^{15}$ The Blackstonian view had a tremendous influence on the common law of press rights, ${ }^{16}$ but has been strongly criticized in the last half-century. ${ }^{17}$ Leading American scholars in the 1920s tried to distance the American common law on freedom of speech and press from its English predecessor. ${ }^{18}$

"Freedom of the press" began to take on a meaning of its own around the time the press became more institutionalized. At the time of the country's founding, the "press" consisted of family newspapers. ${ }^{19}$ By the early twentieth century, the occupation of "journalist"

${ }^{15} 5$ William Blackstone, COMmentaries *142, *150-53. Blackstone thought that society needed to be protected from "abuse" of freedom of the press, not that the press needed to be protected from abuse by government. Id. Some early American commentators, though, were of the opposite opinion. See, for example, a letter written by the Continental Congress in 1794 to Quebec explaining some of the purposes behind the Revolutionary War. Address to the Inhabitants of Quebec, reprinted in 1 THE BILl OF RightS: A DOCUMENTARY History 221, 223 (Bernard Schwartz ed., 1971) (arguing that a free press is necessary, in part, to shame oppressive public officials "into more honourable and just modes of conducting affairs"). Professor Anderson notes that the letter's "view of the purposes of freedom of the press was not limited to scrutiny of government, but also included broader intellectual and cultural objectives." Anderson, supra note 13, at 464.

${ }^{16}$ See Zechariah Chafee, JR., Free Speech 9-10 (1920) (recognizing Blackstonian thought in American free speech theory).

${ }^{17}$ See James A. Guest \& Alan L. Stanzler, The Constitutional Argument for Newsmen Concealing Their Sources, 64 Nw. U. L. REv. 18, 30 (1969) (“[T] he Supreme Court has made it clear that the first amendment guarantee gives wider protection than what was available in England in the late eighteenth century."); Fargo, supra note 13, at 125 (arguing that by the 1960s, the Blackstonian view of free speech, which relied on English common law, was out of favor in U.S. courts, and freedom of the press began to develop a meaning separate from freedom of speech).

${ }^{18}$ See, e.g., 2 HENRY SCHOFIELD, ESSAYS ON CONSTITUTIONAL LAW AND EQUiTy 52122 (1921) (arguing that one of the aims of the American Revolution was to rid the Colonies of "the English common law on liberty of speech and of the press"); see also Fargo, supra note 13, at 105-110 (noting that Schofield, Chafee, and Justice Holmes began in the 1920s to accord the press significantly more protection). For opposition to this civil libertarian perspective, see MARK A. GRABER, TRANSFORMING FrEE SPEECH: The Ambiguous LegACY OF CIVIL LiberTARIANISM 1-3 (1991) (disagreeing with the civil libertarian theories of Chafee, Meiklejohn, and Emerson, and even claiming that Chafee "deliberately manipulated history and theory").

${ }^{19}$ See Fargo, supra note 13, at 71 (noting that prior to the 1830 s most newspapers were family businesses, and, therefore, it was implausible to think of "the press" as an institution distinct from individuals). 
was clearly a profession, and the "press" began to more firmly occupy a place in the American constitutional scheme..$^{20}$

\section{What Should "Freedom of the Press" Mean?"}

Each of the theories discussed in this Part approaches the phrase "freedom of the press" from a different angle, suggesting its importance for the press, for society, or for government. Yet in these competing First Amendment theories there is a striking similarity: each allows for recognition of a privilege for journalists.

Some scholars argue that "freedom of the press" should be conceptually separate from "freedom of speech," and that the former accords the press distinct rights-which are more encompassing-than those associated with speech. For instance, Justice Stewart relies on the role that the press plays in American political society to bolster his argument that press freedoms are greater than speech freedoms. ${ }^{22}$ Similarly, Justice Brennan argues that the most appropriate way to

${ }^{20}$ See David S. Allen, The Institutional Press and Professionalization: Defining the Press Clause in Journalist's Privilege Cases, 34 FREE SPEECH Y.B. 49, 50 (1996) (discussing the professionalization of the press that occurred by the 1920s).

${ }^{21}$ Professor David Anderson notes that several First Amendment scholars, in evaluating today's conception of the Press Clause, largely disregard what the Framers might have meant.

Two of our most prominent first amendment theorists, Chafee and Emerson, warn us that the historical inquiry is futile, either because "the framers had no very clear idea as to what they meant," see Chafee, Book Review, 62 HARV. L. REV. 891, 898 (1949), or because it is impossible at this late date to ascertain what they meant, see Emerson, Colonial Intentions and Current Realities of the First Amendment, 125 U. PA. L. REV. 737 (1977). Our most prominent first amendment historian, Leonard Levy, believes it is possible to ascertain what the Framers meant (to wit: very little), but tells us it does not matter, that we are not bound by their understanding anyway. See L. LEVY, LEGACY OF SUPPRESSION: FREEdOM OF SPEECH AND PRESS IN EARLY AMERICAN History 4 (1960). Anderson, supra note 13, at 461 n.38.

${ }^{22}$ See Potter Stewart, "Or of the Press," 26 Hastings L.J. 631, 633 (1975) ("If the Free Press guarantee meant no more than freedom of expression, it would be a constitutional redundancy."). The "institutional autonomy" argument, first articulated by Justice Stewart, supports the view that the press should be treated differently than the general public. See id. at 633 ("The publishing business is, in short, the only organized private business that is given explicit constitutional protection."); see also TIMOTHY W. Gleason, The Watchdog Concept: The Press and the Courts in NineteenthCENTURY AMERICA 112 (1990) ("[F]reedom of the press is the only individual right in the federal Bill of Rights with an organized, profit-making, institutional constituency. The watchdog concept of freedom of the press is a direct result of that institutional constituency."). 
view the First Amendment is through the "structural" model, ${ }^{23}$ which "significantly extends the umbrella of the press' constitutional protections." ${ }^{24}$ Indeed, C. Edwin Baker worries that the government will infringe on the press's rights unless the press is given "special institutional protection." And Randall Bezanson posits that a "distinct and coherent set of principles should apply to free expression claims by the press." 26

In contrast to the view that press freedoms are greater than speech freedoms, some commentators argue that "freedom of the press" does not provide the institutional press with any rights not available to ordinary citizens. Most courts have endorsed this view. ${ }^{27}$

${ }^{23}$ Address by William J. Brennan, Jr., Associate Justice of the Supreme Court of the United States (Oct. 17, 1979), in 32 RuTGERS L. REV. 173, 176-77 (1979). While the "structural" model "focuses on the relationship of the press to the communicative functions required by our democratic beliefs," $i d$. at 177 , the "speech" model maintains that the First Amendment simply "prohibit[s] any interference with freedom of expression." Id. at 176.

${ }^{24}$ Id. at 177.

${ }^{25}$ C. Edwin Baker, Press Rights and Government Power to Structure the Press, 34 U. MiAmi L. REV. 819, 853 (1980).

${ }^{26}$ Randall P. Bezanson, The Structural Attributes of Press Freedom: Private Ownership, Public Orientation, and Editorial Independence, in JOURNALISM AND THE DEBATE OvER PRIVACY 17, 18 (Craig L. LaMay ed., 2003). First, journalists exercise "editorial judgment" that is fundamentally different from how individuals form their beliefs and make expressive judgments. Id.; see also Randall P. Bezanson, The Developing Law of Editorial Judgment, 78 NEB. L. REV. 754, 757-58 (1999) (describing the body of case law related to claims of editorial freedom). Second, the press comments on matters of public import, while individuals' speech "is, by its very nature, personal and therefore private." Bezanson, The Structural Attributes of Press Freedom, supra, at 18-19. In addition to the public/private distinction, Bezanson identifies what he takes to be the six other fundamental differences between individual and press speech. Id. at 19-20.

${ }^{27}$ See, e.g., McConnell v. Fed. Election Comm'n, 251 F. Supp. 2d 176, 234 (D.D.C. 2003) (noting that the prevailing thought is that "the Press Clause provides no greater rights [than the Speech Clause]"). However, a handful of Justices have specifically argued that journalists deserve special privileges not enjoyed by the general public. See, e.g., Houchins v. KQED, Inc., 438 U.S. 1, 16 (1978) (Stewart, J., concurring) ("The concept of equal access must be accorded more flexibility in order to accommodate the practical distinctions between the press and the general public."); Pell v. Procunier, 417 U.S. 817, 841 (1974) (Douglas, J., dissenting) (noting the important functional differences between access by the press and access by individuals, and arguing for special press accommodations); Saxbe v. Wash. Post, 417 U.S. 843, 863 (1974) (Powell, J., dissenting) (arguing that the press's function as a public watchdog should entitle it to interview prisoners under some circumstances, even when the general public is not accorded such privileges); accord LEE C. BOLLINGER, IMAGES OF A FREE PRESS 20 (1991) (arguing that the laws of "freedom of the press" and "freedom of speech" have been treated separately by several Justices since at least N.Y. Times $v$. Sullivan in 1964). 
This group is split into two camps: one relies on the Blackstonian view of the common law and original intent of the Framers to justify its position that "press" in the First Amendment simply means "written expression" and that the press is not afforded any special constitutional protection. $^{28}$

The other camp walks a more delicate interpretive line: it argues for press protections but not at the expense of added press responsibilities. $^{29}$ If the press receives special rights because it is a "public agent," then the public can theoretically assert control over the press. ${ }^{30}$ And the most practicable means of the public asserting this control is through the government, which can more easily implement such mechanisms. ${ }^{31}$ Paradoxically, granting the press special rights under the First Amendment could actually lead to the press's loss of independence from the government. ${ }^{32}$

Thomas Emerson and Laurence Tribe subscribe to the view that special press protections are tied to special press responsibilities. Emerson argues that freedom of the press is just one component in the protection afforded by the First Amendment to "an integrated system of freedom of expression." ${ }^{33}$ Tribe argues that the press as an institution does not need "extraordinary constitutional protection," but that the interplay between the First and Fourth Amendments creates a unique situation that requires more sensitivity to journalists' role in society. ${ }^{34}$ Tribe's argument, though, rests on an ill-defined middle

${ }^{28}$ See, e.g., Nimmer, supra note 14, at 640 (suggesting that the Framers protected the press because of concerns that speech would be limited to oral expression).

${ }^{29}$ See William W. VAN Alstyne, InTERPRETAtions OF THE FirST AMENDMENT 59-60 (1984) (advocating First Amendment protections for the press, but disagreeing with the notion that these privileges are warranted because the press is an agent of the people). For specific opposition to this view, see Pennekamp v. Florida, 328 U.S. 331, 354-55 (1946) (Frankfurter, J., concurring) (arguing that a free press is necessary for a free society, but that society can mandate that the press act responsibly).

${ }^{30}$ See VAN ALSTYNE, supra note 29, at 59-60 (suggesting that if the press were an agent of the public, the public could dictate what is to be published).

${ }^{31}$ Cf. id. (noting that shortly after printing presses were invented, the English government, concerned about the hazards of the new technology, sharply regulated the press).

${ }^{32}$ See id. at 65 (explaining that by enjoying special privileges newspapers may lose editorial liberty); see also Anthony L. Fargo, The Journalist's Privilege for Nonconfidential Information in States Without Shield Laws, 7 COMM. L. \& POL'Y 241, 252 (2002) (“[T]he logical conclusion of providing the press with special First Amendment protections might be the death of [the press's] independence from government interference.").

${ }^{33}$ Thomas I. Emerson, Freedom of the Press Under the Burger Court, in THE BuRGER COURT: THE COUNTER-REVOlution THAT WASN'T 1, 3 (Vincent Blasi ed., 1983).

${ }^{34}$ LAUREnCE H. Tribe, AMERican CONSTITUtional LAW 976 (2d ed. 1988). 
ground: while the press should not have special protections, it should also not be regulated the same as an ordinary type of business. ${ }^{35}$

\section{Other Relevant Theories Supporting the Journalist's Privilege}

One theory undergirding the journalist's privilege is the "right to know." ${ }^{36}$ Under this theory, the people have a right to know certain information, but because of the complexity of today's society, and time and information constraints on individuals, citizens are unable to personally get the information they require. ${ }^{37}$ Enter the press, whose role is to provide individuals with such information. In this respect, the press acts as an agent of the people. This theory also implicates some of the problems associated with granting the press special rights: for example, if the press's rights are derived from its service to the people, then the people (or their extension, the government) can exercise dominion over the press.

Another theory supporting the journalist's privilege is that the press's role is to act as a check on government. ${ }^{38}$ Some variations of this theory argue that the press is a "watchdog," ${ }^{39}$ keeping an eye on government, or that the press is a Fourth Estate, ${ }^{40}$ exercising its political power for the good of the people. ${ }^{41}$ The press again acts as an

${ }^{35}$ See id. ("Legal procedures that threaten the confidentiality of reporters' sources or disrupt the editorial process clearly implicate constitutional concerns not present when ordinary businesses are searched or most professionals questioned about their work ....").

${ }^{36}$ The phrase "the right to know" was coined in a 1945 speech by journalist Kent Cooper. DAVID M. O'BriEN, The Public's Right TO KNOW 2 (1981).

${ }^{37}$ See Thomas I. Emerson, Legal Foundations of the Right to Know, 1976 WASH. U. L.Q. 1, 5-7 (arguing that the right to know protects the system of free expression from governmental interference and guarantees the availability of information from governmental and certain private sources).

${ }^{38}$ See, e.g., Vincent Blasi, The Checking Value in First Amendment Theory, 1977 AM. B. FOUND. RES. J. 521, 537 (1977) (noting that Thomas Jefferson supported the "checking value" of freedom of the press).

${ }^{39}$ See, e.g., GLEASON, supra note 27, at 112 (suggesting that the press should enjoy special protection because of its role in conveying information to the public about the government and other public institutions).

${ }^{40}$ See, e.g., Lucas A. Powe, JR., The Fourth Estate and the Constitution: FREEDOM OF THE PRESS IN AMERICA 260-62 (1991) (referring to the press as a "fourth estate" that oversees the government).

${ }^{41}$ See, e.g., JOHn Lofton, The Press as GuARdian of The First Amendment xii (1980) (characterizing the press as "the vehicle and the symbol of unfettered expression" and postulating that the press, unlike other institutions, is willing to confront the government). 
agent of the people, serving their will by monitoring the other three branches of government and keeping the people informed of any misdeeds.

\section{The Marketplace of Ideas and Individual Liberty Paradigms}

The paramount concern for subscribers to the marketplace of ideas $^{42}$ paradigm is that information reach the audience. As Alexander Meiklejohn phrased it, "What is essential is not that everyone shall speak, but that everything worth saying shall be said." ${ }^{43}$ Conversely, under an individual liberty paradigm, the paramount concern is that individuals are able to express themselves. According to Baker, the First Amendment is focused on the role of the speaker, not on the speaker's impact on society. ${ }^{44}$

For those adhering to the marketplace of ideas interpretation of the First Amendment, a privilege for journalists makes intuitive sense because it encourages the dissemination of more information (and more valuable information) "so that everything worth saying shall be said." For adherents of the individual liberty interpretation of the First Amendment, however, a journalist's privilege is not as indispensable.

A non-human entity such as a newspaper does not receive the same satisfaction from engaging in expression as a person does, and is

${ }^{42}$ The "marketplace of ideas" metaphor, with its philosophical roots in JOHN STUART Mill, On LiberTy (1859), and JOHn Milton, AREOPAGitica (1644), was first coined by Justice Holmes in the 1920s. Fargo, supra note 13, at 89 n.137.

${ }^{43}$ Alexander Meiklejohn, Political Freedom: The Constitutional Powers OF THE PEOPLE 26 (1965). Meiklejohn argued that the societal interest in free speech outweighed the private interest in free speech. AlEXANDER MEIKLEJOHN, FrEe SPEECH AND ITS RElation to SElf-Government 62 (1948). He believed that the First Amendment's language was absolute, and therefore that the societal interest in free speech could not be abridged. Id. For him, protection for the interests of private speech were adequately protected by the Fifth Amendment. Id. at 63.

For an elaboration of the impact of the Meiklejohn view on the courts and a discussion of the view that an absolute right to free speech allows the people to govern themselves, see William J. Brennan, Jr., The Supreme Court and the Meiklejohn Interpretation of the First Amendment, 79 HARV. L. REV. 1, 11-12 (1965).

${ }^{44}$ See C. Edwin Baker, Scope of the First Amendment Freedom of Speech, 25 UCLA L. REV. 964, 995-96 (1978) (maintaining that the right to free speech is valuable because it allows individual self-fulfillment). Though Baker views the Speech and Press Clauses as conceptually separate, see C. EDWIN BAKER, HuMAN LIBERTY AND FREEDOM OF SPEECH 229 (1989) [hereinafter BAKER, HuMAN LIBERTY]; C. Edwin Baker, Turner Broadcasting: Content-Based Regulation of Persons and Presses, 1994 SuP. CT. REV. 57, 62-64, his expressed views of the Speech Clause inform some of the paradigms of the First Amendment expressed in this Part. 
therefore not accorded the same First Amendment protections. Nevertheless, proponents of the individual liberty theory still argue for a privilege for journalists, ${ }^{45}$ mostly because a citizen cannot fully express herself without the greatest amount of information.

\section{Conclusion}

Support for the journalist's privilege is found in varying interpretations of the First Amendment. Each conceptualization of "freedom of the press" and the First Amendment implicates a different facet of the journalist's privilege debate, and the theoretical arguments in favor of a journalist's privilege necessarily depend on how one interprets the meaning of "freedom of the press" in the First Amendment. It is not the place of this Comment to provide a comprehensive theory of the First Amendment; rather, each First Amendment theory provides a slightly different paradigm through which to view the journalist's privilege debate. Nevertheless, each theory, in its own way, supports the privilege.

\section{B. Testimonial Privileges}

Privileges are generally disfavored in our judicial system, but there is a recognition that some societal values sometimes outweigh the value in procuring evidence during trials. These privileges typically protect a confidential communication between two parties, such as attorney-client, doctor-patient, or husband-wife, in which the need for open and frank discussion between the parties is so important that the judiciary does not compel their production at trials. ${ }^{46}$ The traditional four-part test for determining the validity of an asserted privilege was propounded by Professor John Henry Wigmore in 1904, and is often cited by courts today:

\footnotetext{
45 See BAKER, Human LIBERTY, supra note 44, at 245 ("Unless a member of the press appears to have engaged in criminal conduct-which may give her a fifth amendment privilege-she should not be required to answer questions about her investigations or her sources.").

${ }_{46}$ The fundamental question in this area is whether there is a net benefit to society. Older notions (such as the idea that there is a special relationship between the attorney and the client that society values for some nonconsequentialist reason) have largely fallen by the wayside. See, e.g., Note, Attorney-Client and Work Product Protection in a Utilitarian World, 108 HARV. L. REV. 1697, 1699 (1995) (analyzing the modern trend toward the use of utilitarian reasoning to justify privileges).
} 
(1) The communications must originate in a confidence that they will not be disclosed.

(2) This element of confidentiality must be essential to the full and satisfactory maintenance of the relation between the parties.

(3) The relation must be one that in the opinion of the community ought to be sedulously fostered.

(4) The injury that would inure to the relation by the disclosure must be greater than the benefit thereby gained for the correct disposal of litigation. ${ }^{47}$

Wigmore's criteria, which tend to support the traditional privileges, ${ }^{48}$ do not lend themselves to the creation of a journalist's privilege. ${ }^{49}$ Over the past hundred years, however, Wigmore's factors, while still relevant, have been superseded by a more expansive vision of evidentiary privileges. The journalist's privilege, while arguably unnecessary in 1904, fits nicely into the legal atmosphere of 2005.

The journalist's privilege is almost the inverse of the other privileges that have long been protected at common law. The traditional privileges protect the substance of the communication; the identity of the speaker is already known. The journalist's privilege protects the source of the communication; the substance of the communication is already known. In addition, the traditional privileges are pierced by disclosing communication to a third party; the journalist's privilege is premised on the idea that the communication already has been disclosed to numerous third parties. Finally, with traditional privileges, the speaker holds the right to the privilege, and can waive that right. With the journalist's privilege, the journalist (i.e., the recipient) is the

${ }^{47}$ WigMORE ON EVIDENCE, supra note $1, \S 2285$, at 527.

${ }^{48}$ For an interesting argument on why communications to journalists are even more in need of protection than communications to doctors or lawyers, see Abraham S. Goldstein, Newsmen and Their Confidential Sources, THE New RePublic, Mar. 21, 1970, at 13-15. Goldstein argues that the person making the statement to a doctor or lawyer is doing so because of an urgent need for the professional's help; for the client or patient, fear of disclosure at a later date is usually outweighed by the need for immediate assistance. Id. For the person communicating with the journalist, though, the reasons behind the communication are usually some combination of advancing the public good, the prospect of financial gain, or spite. Id. Therefore, this informant, who does not urgently need the journalist's assistance, will be more likely than a person communicating with a doctor or lawyer to withhold information due to risk of future exposure. Id

${ }^{49}$ The Supreme Court even cited Wigmore in rejecting the privilege in Branzburg. 408 U.S. 665, 690 n.29 (1972). See also VAN GERPEN, supra note 6, at 60 ("In applying Wigmore's conditions, many courts deny reportorial privilege."). 
keeper of the privilege; the speaker cannot waive the privilege after the fact. ${ }^{50}$

The reporter's privilege, then, is most akin to the governmentinformer privilege, which also protects the source of the communication rather than the communication itself. ${ }^{51}$ This privilege "recog-

${ }^{50}$ See Paul F. Rothstein \& Susan W. Crump, Federal Testimonial Privileges: Evidentiary Privileges Relating to Witnesses \& Documents in Federal-LaW CASES 590 (2d ed. 2003) (noting that neither the news source nor the public has standing to assert or waive the privilege); see also 23 CHARLES ALAN WRIGHT \& KENNETH W. Graham, JR., FEDERAL PRACTICE AND Procedure $\$ 5426$, at 796 (1980) ("[I]t is rather unusual in the law of privileges to make the recipient rather than the communicator the holder of a privilege for confidential communications."). However, ownership of the privilege is not a settled legal matter. See, e.g., Howard Kurtz, Legal Analysts Critical of N.Y. Times Reporter's Stance in Leak Probe, WASH. POST, July 13, 2005, at A7 (quoting First Amendment scholar Professor Geoffrey Stone that "[i]t's the source's privilege, not the reporter's. . . As a legal matter, it's absurd [to argue otherwise]").

In fact, there is debate over how to determine if a source has voluntarily waived the privilege ex post, including whether that is possible, and if so, whether it is even relevant. How could such a waiver be voluntary if it is mandated by one's employer on the threat of dismissal for refusal to sign? In the Judith Miller case, and in the Justice Department investigation into the source of the leaks during the anthrax investigation of scientist Stephen Hatfill, the federal government "asked" (the term is used loosely here) administration officials and Justice Department employees to sign waivers releasing all journalists from pledges of confidentiality they might have made. See Kurtz, supra, at A7 (quoting First Amendment attorney Floyd Abrams as saying that waivers in the form of "preprinted forms from the Department of Justice that people were instructed to sign by their superiors[] do not constitute the sort of waivers a journalist ought to accept as truly freeing the journalist from the obligation of confidentiality"); Carol D. Leonnig, 2 Reporters in Leak Case Given 48 Hours to Argue Against Jailing, WASH. Post, June 30, 2005, at A2 (quoting Chief Judge Hogan, who said that "[ $\mathrm{t}]$ he sources have waived their confidentiality" and are therefore "not relying on the promises of the reporters"); Scott Shane, Anthrax Figure Wins a Round on News Sources, N.Y. TIMES, Oct. 22, 2004, at A12 (noting that the Department of Justice asked employees to sign "Plame waivers" releasing journalists from their pledges of confidentiality, and recognizing media experts' worry that such waivers were becoming an "established legal tool”); see also Pete Yost, Reporter Won't Talk, Goes to Jail, CHI. Sun-Times, July 7, 2005, at 4 (noting that Matt Cooper decided to provide testimony to the grand jury because his source gave him a "waiver" immediately before he was to be sentenced for contempt).

${ }^{51}$ See Proposed Federal Rule of Evidence 510, 56 F.R.D. 183, 255-56 (1973) (giving ownership of the privilege to the government, the recipient of the information, rather than the informant, the speaker of the information). The irony here is that Wigmore was adamantly in favor of the government-informer privilege. See Karl H. Schmid, Journalist's Privilege in Criminal Proceedings: An Analysis of United States Court of Appeals' and State High Courts' Decisions from 1973 to 1999, at 327 (2001) (unpublished Ph.D. dissertation, University of North Carolina at Chapel Hill) (on file with the University of Pennsylvania Law Review) (noting that Wigmore, while "vehemently oppos[ing] the journalist's privilege . . . believed that the government-informer privilege was a sound principle of law" (citing WIGMORE ON EVIDENCE, supra note 1, § 2192, at 70-74)). In addition, the Supreme Court has twice endorsed the idea of a government- 
nizes the use of informers as an important aspect of law enforcement" and concludes that the societal interest in law enforcement's use of informers often outweighs the judicial interest in obtaining all relevant evidence in a given case. ${ }^{52}$

The journalist's privilege poses special theoretical and procedural issues for courts because it lacks the conceptual clarity and storied history of, say, the attorney-client privilege, and, in many ways, is the inverse of the traditional privilege relationship. Unfortunately, courts often use these recurring issues as an excuse for denying the privilege when, in fact, the privilege would be robust if it were not viewed under the paradigm of Wigmore's four criteria and the traditional notion of a testimonial privilege. In short, society would be better served if courts looked at the privilege outside of the traditional Wigmorean scheme and were more understanding of the unique role that the journalist's privilege plays in our democratic society.

Wigmore, writing in 1904, may have had views of the press and press privileges that were not conducive to this privilege; moreover, courts, as discussed more fully in Part IV, have been loath to recognize privileges for additional professional groups. ${ }^{53}$ But, as the robust support for the government-informer privilege demonstrates, the public interest in allowing certain confidences can be quite significant, and the procedural complaints that the privilege is too cumbersome to administer should not drown out the important role that a privilege for journalists will play in our society.

\section{The Contours of the Journalist's Privilege}

The term "journalist's privilege," generally to the right of journalists to refuse to answer subpoenas-a right the Supreme Court has never recognized. However, the privi-

informer privilege. See McCray v. Illinois, 386 U.S. 300 (1967); Roviaro v. United States, 353 U.S. 53 (1957).

${ }^{52} 56$ F.R.D. at 256.

${ }^{53}$ In addition, current privilege-holding professional groups also disfavor granting new privileges. See Sissela Bok, SECRETS: ON THE ETHICS OF CONCEAlMENT AND REVELATION 119 (1983) ("Every newly established professional group seeks the privileges of existing ones. Established ones, on the other hand, work to exclude those whom they take to be encroaching on their territory."). But see WRIGHT \& GRAHAM, supra note 50, 55426 , at 720-22 (arguing that "journalists are entitled to parity with other professional groups," in part because reporters often hold the ethical canons of their profession in higher regard than court orders).

${ }^{54}$ The journalist's privilege is also known as the "reporter's privilege," "reportorial privilege," or "newsman's privilege." 
lege comes in many forms: it can be absolute or qualified, and can be applied differently depending on the subpoenaing party, type of case, and category of evidence. In addition, there is an ongoing scholarly debate regarding the contours of the privilege and who should be able to claim it. ${ }^{55}$

At the outset, most jurisdictions do not allow journalists to assert the privilege for eyewitness accounts. ${ }^{56}$ So if a person-journalist, elected official, or ordinary citizen-witnesses a crime, she has a duty to provide testimony. ${ }^{57}$

An absolute privilege protects journalists from having to give any testimony or produce any documents. A qualified privilege, on the other hand, allows the journalist to assert the privilege, but allows a judge to rule that the interests of the case at bar outweigh the journalist's interests. There are two traditional tests to determine if a particu-

${ }^{55}$ See Laurence B. Alexander, Broadening the Scope of the Newsgathering Privilege to Protect Nontraditional Journalists: A Definitional Dilemma 25 (Aug. 2000) (Research Paper, Law Division, Association for Education in Journalism and Mass Communication, on file with the University of Pennsylvania Law Review) ("So daunting was the task of determining the sphere of protection that the Branzburg court gave it no attention."). Compare, e.g., $i d$. at 27-28 (arguing for a totality of the circumstances approach to determine who is a journalist and is therefore accorded the journalist's privilege, and cautioning against over-application of the privilege), with Julie Hilden, Can Bloggers Invoke the Journalist's Privilege to Protect Confidential Sources Who Leak Trade Secrets? A Suit Filed By Apple Computer Raises the Question, FINDLAW'S WRIT LEGAL COMMENTARY, Apr. 26, 2005, http://writ.findlaw.com/hilden/20050426.html (arguing for a much more expansive definition of "journalists" entitled to the privilege), and Eugene Volokh, You Can Blog, But You Can't Hide, N.Y. TIMES, Dec. 2, 2004, at A39 ("[T] he rules should be the same for old media and new, professional and amateur. Any journalist's privilege should extend to every journalist.”).

${ }_{56}$ See, e.g., United States v. Criden, 633 F.2d 346, 360 (3d Cir. 1980) (finding a journalist guilty of civil contempt for refusing to affirm or deny she had a conversation that was relevant to a criminal proceeding); United States v. Steelhammer, 561 F.2d 539, 540 (4th Cir. 1977) (affirming a district court judgment of contempt for reporters who refused to testify about events they witnessed at a union rally). But see Delaney v. Superior Court, 789 P.2d 934, 940 (Cal. 1990) (construing California's shield law as protecting journalists from contempt citations for failure to provide eyewitness testimony).

${ }^{57}$ Jeremy Bentham is often cited for the proposition that all persons have to submit to give testimony:

Were the Prince of Wales, the Archbishop of Canterbury, and the Lord High Chancellor, to be passing by in the same coach, while a chimney-sweeper and a barrow-woman were in dispute about a halfpennyworth of apples, and the chimney-sweeper or the barrow-woman were to think proper to call upon them for their evidence, could they refuse it? No, most certainly.

4 The Works of JeREMY Bentham 320-321 (John Bowring ed., 1843); see also Branzburg v. Hayes, 408 U.S. 665, 689 n.26 (1972) (citing Bentham’s quip). 
lar litigant can pierce the qualified privilege. One is a three-part test derived from Justice Stewart's dissent in Branzburg. ${ }^{58}$ The other is a balancing test, in which the judge weighs the journalist's interest in non-disclosure against society's interest in disclosure. ${ }^{59}$

The type of proceeding often dictates a court's determination of whether the privilege exists (and the contours of the privilege). The Supreme Court clearly held in Branzburg ${ }^{60}$ that journalists have no privilege to refuse to answer grand jury subpoenas. The law as to subpoenas made in the course of a criminal trial or civil trial, though, is indeterminate. Some courts afford journalists less protection in criminal trials because of what the courts see as a stronger societal interest in the outcome of the case than in civil trials, and also because the individual implications for the defendant (i.e., jail time) are arguably more important. ${ }^{61}$ However, within criminal trials, some courts

${ }^{58}$ See infra text accompanying note 92 (outlining the test).

${ }^{59}$ See, e.g., Branzburg v. Hayes, 408 U.S. 665, 710 (1972) (Powell, J., concurring) (advocating that courts, on a case-by-case basis, strike a "proper balance between freedom of the press and the obligation of all citizens to give relevant testimony with respect to criminal conduct"); State v. Salsbury, 924 P.2d 208, 213 (Idaho 1996) (establishing a balancing test for a qualified reporter's privilege); Classic III, Inc. v. Ely, 954 S.W.2d 650, 655 (Mo. Ct. App. 1997) (same).

Of course, when presented as the journalist's individual interest versus society's interest, it is no surprise that society often wins. One commentator argues, therefore, that the situation should be presented as societal interest versus societal interest (i.e., society's interest in the free flow of information versus society's interest in identifying the source of the information). See Margaret Sherwood, Comment, The Newsman's Privilege: Government Investigations, Criminal Prosecutions and Private Litigation, 58 CAL. L. REV. 1198, 1219 (1970) (criticizing one court for labeling the "litigant's right to compelled testimony a 'public' interest and the newsman's right to non-disclosure a 'private' one"); see also VAN GERPEN, supra note 6, at 87 (noting that the privilege asserted by journalists is a public right, as opposed to the private right of privacy protected by the Fourth Amendment, which is at the heart of the privileges that protect communications with doctors, lawyers, and ministers). Indeed, one can even conceive of the scales tipping further, such as society's interest in the free flow of information versus an individual litigant's desire for that information. When the argument is formulated in this manner, the journalist should win. Much therefore depends on whether the journalist is seen as representing a personal interest or societal interest.

${ }^{60}$ See infra Part II.A for a further discussion of the case.

${ }^{61}$ See, e.g., United States v. LaRouche Campaign, 841 F.2d 1176, 1182 (1st Cir. 1988) (relying on the fact that the case was criminal in denying the journalist's privilege). In addition, while the Sixth Amendment affords criminal defendants the right to compel evidence, there is no such analogous provision in the Seventh Amendment, which applies to civil trials. Compare U.S. CONST. amend. VI ("[T] he accused shall enjoy the right ... to have compulsory process for obtaining witnesses in his favor ....”), with U.S. CONST. amend. VII (failing to guarantee such a process for civil trials). 
may be more deferential to prosecution rather than defense subpoenas. ${ }^{62}$

The confidentiality of the materials sought often plays a large role in the amount of protection given by the courts. The identity of the source of the information is usually confidential: this is the traditional "anonymous source" that journalists strive so earnestly to protect. Tangible material that is meant to remain confidential (usually a document) often receives a slightly lesser degree of protection. Finally, some courts afford less protection to non-confidential information. ${ }^{63}$ This is information that journalists strive to protect because of the "integrity" of their profession and the supposed intrusion into their editorial process, ${ }^{64}$ rather than because they promised a source they would keep her identity a secret. Nonconfidential information takes the form of television "outtakes," ${ }^{65}$ photographs taken in public places, and journalists' work product.

Finally, any discussion of a potential journalist's privilege must take into account the specific definition of a journalist. ${ }^{66}$ State laws providing a journalist's privilege are not in agreement on the matter, ${ }^{67}$ and different federal circuits have promulgated different tests to determine if someone qualifies as a "journalist." ${ }^{68}$ Some jurisdictions

${ }^{62}$ See Schmid, supra note 51, at 181-83 (showing empirically that federal appellate courts are significantly more favorable to prosecution and grand jury subpoenas than criminal defendant subpoenas).

${ }_{63}^{63}$ See, e.g., Gonzales v. Nat'l Broad. Co., 194 F.3d 29, 35-36 (2d Cir. 1999) (affording less protection to nonconfidential materials than confidential materials). The law in this area, as in most other areas dealing with journalist's privilege, varies widely depending on the particular federal circuit. Compare United States v. Smith, 135 F.3d 963, 972 (5th Cir. 1998) (providing no protection for nonconfidential materials), with LaRouche, $841 \mathrm{~F} .2 \mathrm{~d}$ at 1182 (giving the same amount of protection to both confidential and nonconfidential materials).

${ }^{64}$ Note, though, that the Supreme Court has held that the press has no right to shield its internal editorial processes. See Herbert v. Lando, 441 U.S. 153, 176 (1979) (refusing to "creat[e] a constitutional privilege [that] foreclose[s] direct inquiry into the editorial process").

${ }^{65}$ An "outtake" is film that was taped with the intention of being aired, but that was cut out of the segment by editors. See Alison Lynn Tuley, Note, Outtakes, Hidden Cameras, and the First Amendment: A Reporter's Privilege, 38 WM. \& MARY L. REV. 1817, 1818 n.13 (1997) (defining an outtake as "unbroadcast videotaped material").

${ }^{66}$ See supra notes 53-55 (staking out the varying positions in the debate over who is a "journalist" and should be accorded the privilege).

${ }^{67}$ See Laurence B. Alexander \& Leah G. Cooper, Words That Shield: A Textual Analysis of the Journalist's Privilege, NEWSPAPER RES. J., Winter/Spring 1997, at 51, 55 (1997) (noting the wide disparity in state shield laws' definitions of "journalist").

${ }^{68}$ See, e.g., von Bulow v. von Bulow, 811 F.2d 136, 142 (2d Cir. 1987) (enumerating five principles used to determine whether a person is entitled to claim a journalist's 
only allow the institutional press to assert the privilege, while others allow independent "one-time" journalists to do so. ${ }^{69}$ Book authors are sometimes not accorded the privilege, ${ }^{70}$ nor sometimes are freelance, student, or non-profit journalists. And with the advent of the Internet and blogs, the line between journalist and tech-savvy citizen is continually blurred. ${ }^{71}$

In spite of this definitional problem there is no debate that mainstream, traditional newspaper and television reporters would qualify as journalists under a potential privilege.

privilege). The court emphasized that the test of whether someone was a journalist was whether, at the time she did the reporting or investigating, she had the intent to disseminate the information to the public. Id. at 145; see also Kraig L. Baker, Comment, Are Oliver Stone and Tom Clancy Journalists? Determining Who Has Standing to Claim the Journalist's Privilege, 69 WASH. L. REV. 739, 755 (1994) (advocating the adoption of the von Bulow test "to determine whether an individual or group has standing to claim the journalist's privilege" because (1) "it is consistent with the goals and concerns that underlie the journalist's privilege," (2) it is flexible enough to "apply to new ways of communicating information," and (3) deference should be given to the Second and Ninth Circuits, which have adopted the test, because they are experts in the area of media litigation).

For some circuits, though, the von Bulow test is not sufficient. See, e.g., In re Mark Madden, 151 F.3d 125, 130 (3d Cir. 1998) (requiring, in addition to an intent to disseminate, "investigative reporting").

${ }^{69}$ See Alexander \& Cooper, supra note 67, at 56-57 (detailing the various definitions of and protections for "journalists" under state law).

${ }^{70}$ See, e.g., REPORTERS COMM. FOR FREEDOM OF THE PRESS, AGENTS OF DisCOVERY: A REPORT ON THE INCIDENCE OF SubPoEnAS SERVED IN THE NEWS MEdia IN 2001, at 3 (2003), available at http://www.rcfp.org/agents/agents.pdf [hereinafter AGENTS OF DISCOVERY] (noting that a book author recently went to jail for refusing to disclose her confidential source).

${ }^{71}$ The famous quip by journalist A.J. Liebling is therefore losing its relevance. A.J. Liebling, The Wayward Press: Do You Belong in Journalism?, New YORKER, May 14, 1960, at 105, 109 ("Freedom of the press is guaranteed only to those who own one."). For a current story that melds journalist's rights with new technology, see Jonathan Finer, Teen Web Editor Drives Apple to Court Action, WASH. POST, Jan. 14, 2005, at A1 (noting that the 19-year-old student operator of an Apple Computer-related technology website is asserting his First Amendment reportorial rights as a defense against Apple's trade secret lawsuit against him); see also Amicus Curiae Brief of Bear Flag League for Petitioners in Part and Real Party in Interest in Part at 4, O'Grady v. Superior Court, No. H028579 (Cal. Ct. App. filed Apr. 15, 2005), available at http://socallawblog.com/wpcontent/BFLAmicusBrief.pdf (arguing in the Apple Computer case that Internet news sites and bloggers who qualify as "news gatherers" or "news reporters" should be treated as journalists and accorded a journalist's privilege). But see Hilden, supra note 55 (arguing that the Bear Flag League made a "tactical mistake" in its amicus brief by drawing a line between bloggers who qualify as repeat news gatherers and those who do not; Hilden "would deem any blogger a journalist" and grant the privilege). 


\section{STATE OF THE LAW}

The seminal case in this area-Branzburg $v$. Hayes ${ }^{72}$ - seemed to $^{2}$ rule against a privilege for journalists, but it has left an unclear legacy, and its holding has been distinguished by courts of appeals and limited by state legislatures almost from the outset. The evolution of the journalist's privilege is thus an example of how an unclear Supreme Court precedent has fomented significant developments in the common law, culminating in a point where the common law now requires recognition of the privilege at the national level.

\section{A. Federal Case Law}

In Branzburg, a five-member majority ${ }^{73}$ of the Court held that, absent two specific and infrequent circumstances, ${ }^{74}$ journalists have no federal right to refuse to provide testimony when subpoenaed by a grand jury. ${ }^{75}$ The case was a consolidation of four lower court cases (three state, one federal) involving three reporters, one each from Kentucky, California, and Massachusetts. ${ }^{76}$ The Court addressed the limited question of whether reporters have the same obligation as ordinary citizens to respond to grand jury subpoenas seeking informa-

${ }^{72} 408$ U.S. 665 (1972).

${ }^{73}$ Justice White wrote the opinion, and was joined by Chief Justice Burger and Justices Blackmun, Powell, and Rehnquist. Id. at 667.

${ }^{74}$ See id. at 707-08 (excepting inquiries not in good faith and those designed to "disrupt a reporter's relationship with his news sources").

Id. at 708-09.

${ }^{76}$ Paul Branzburg was a reporter for the Louisville Courier-Journal in Kentucky who had written about illegal drug manufacturing and use and was subpoenaed by a state grand jury to testify about the information in his story. The Kentucky Court of Appeals, the state's high court at the time, ordered Branzburg to respond to the grand jury's subpoena. Branzburg v. Meigs, 503 S.W.2d 748 (Ky. 1971); Branzburg v. Pound, 461 S.W.2d 345 (Ky. 1970). Earl Caldwell was a reporter for the New York Times who had written about the Black Panther Party in California. A federal grand jury subpoenaed him for documents and testimony, and the Ninth Circuit upheld his refusal to appear or produce documents. Caldwell v. United States, 434 F.2d 1081 (9th Cir. 1970). Paul Pappas was a television news reporter stationed in Providence, Rhode Island, who had covered the Black Panthers in New Bedford, Massachusetts. The Massachusetts Supreme Judicial Court ordered him to respond to a grand jury subpoena seeking his testimony. In re Pappas, 266 N.E.2d 297 (Mass. 1971).

For the procedural history and detailed factual background of the cases, see Branzburg, 408 U.S. at 667-679; VAN GERPEN, supra note 6, at 104-25. For the D.C. Circuit's legal analysis of the case, see In re Grand Jury Subpoena, Judith Miller, 397 F.3d 964, 968-72 (D.C. Cir.), cert. denied, 125 S. Ct. 2977 (2005). For one reporter's account of the ordeal, see Earl Caldwell, "Ask Me. I Know. I Was the Test Case,"SATURDAY REV., Aug. 5, 1972, at 4 . 
tion relevant to the commission of a crime. ${ }^{77}$ The Court answered the question in the affirmative, specifically declining to create a First Amendment-based testimonial privilege excusing reporters from giving testimony to grand juries. ${ }^{78}$ The Court based its decision on both the lack of concrete evidence that news flow would be inhibited without a testimonial privilege ${ }^{79}$ and the lack of support for a journalist's privilege in both the common law ${ }^{80}$ and Wigmore's criteria. ${ }^{81}$ In addition, the Court noted the duty that journalists, like all citizens, have to give evidence, explicitly rejecting "the theory that it is better to write about crime than to do something about it."

While Justice Powell's vote was necessary to garner a majority, his three-paragraph concurrence is widely seen as limiting the effect of

${ }^{77} 408$ U.S. at 682.

${ }^{78} \mathrm{Id}$. at $690-91$.

${ }^{79} I d$. at 693-94. For a critique of the Court's reliance on empirical evidence, see infra Part IV.B.

${ }^{80}$ See supra note 12 (explaining the Branzburg Court's confusion of the constitutional and common law bases for the privilege).

${ }^{81} I d$. at 690 n.29; see also supra text accompanying note 47 (listing Wigmore's criteria).

${ }^{82} I d$. at 692 . The Supreme Court implies that providing evidence against a criminal at trial is a better way to serve society than simply writing about the crime in a newspaper. The Court missed the point, though, because for journalists, writing about crime is their way of "do[ing] something about it." See Fargo, supra note 13, at 548 (criticizing the majority in Branzburg for "misinterpret[ing] the role of an independent press in a self-governing society"). The press's accomplishments in this role have proven very effective in the past for bringing about needed change. See Elizabeth Zuckerman, Reporters Say There are Reasons for Shielding Sources, BOSTON GLOBE, Nov. 20, 2004, available at http://www.boston.com/news/local/rhode_island/articles/2004/11/20/ reporters_say_there_are_reasons_for_shielding_sources/ (quoting David Kidwell, a Miami Herald reporter who went to jail for refusing to testify in Kidwell v. State, 730 So. 2d 670 (Fla. 1998), as remarking: "We don't have badges and guns. All we have is our word." (internal quotation marks omitted)).

Sometimes, a journalist can do far more good by bringing an issue to the public's attention than by testifying in a court proceeding. For example, a confidential source provided a reporter in San Francisco with documents related to professional baseball players' steroid use from a sealed grand jury proceeding. By testifying as to the identity of the leak, the reporter would have helped solve a relatively minor courtroom procedural infraction. However, by writing about the scandal, the reporter fomented national media and public attention to the issue, extensive congressional hearings, and, most importantly, a reworking of Major League Baseball's drug policy. See generally T.J. Quinn, BALCO Out of Juice, DAILY NEWS (New York), July 17, 2005, at 60. The publicand democracy-is often best served when journalists publicize wrongdoing.

For several contemporary examples of public wrongdoing that came to light only due to reporters' pledges of confidentiality, see Comm. on Commc'ns \& Media Law, Ass'n of the Bar of the City of New York, The Federal Common Law of Journalists' Privilege: A Position Paper, 60 RECORD 214, 225-27 (2005), available at http://www.abcny.org/ Publications/record/vol.\%2060\%20no.\%201.pdf. 
the majority opinion. ${ }^{83}$ Indeed, Justice Powell's concurrence is often thought to be a kind of dissent, leaving the majority as only a plurality. ${ }^{84}$ Rejecting the majority's view that no privilege exists, Justice Powell implicitly recognized such a privilege and advocated balancing "these vital constitutional and societal interests on a case-by-case basis. ${ }^{, 55}$ Justice Powell ended his concurrence with a statement that seemingly contradicts the majority's explicit holding: "the courts will be available to newsmen under circumstances where legitimate First Amendment interests require protection."

Ironically, although the majority opinion seemed to be clear in holding that no journalist's privilege exists, many lower courts that have tackled the issue have emphasized Justice Powell's concurrence as the very reason for finding a journalist's privilege in other circumstances. ${ }^{87}$ One commentator notes that Justice Powell, who had been on the bench only a few months, joined the majority opinion only because he was unsure of his proper role, and this inexperience on the High Court is what led to his "unorthodox concurring opinion." 88 Another account notes that he joined the majority opinion only "[a]fter much hesitation," and gives him much more credit for his actions, arguing that he was so cognizant of his role that he "used his crucial swing vote to limit the effect of [the] majority opinion." 89

${ }^{83} 408$ U.S. at 709 (Powell, J., concurring) ("I add this brief statement to emphasize what seems to me to be the limited nature of the Court's holding.").

${ }^{84}$ See, e.g., In re Selcraig, 705 F.2d 789, 792 (5th Cir. 1983) (wrongly labeling Branzburg a "plurality"). Even one of the Justices involved in the case, Potter Stewart, did not see the case as a majority win. See Stewart, supra note 22, at 635 (referring to the vote count in Branzburg, rather than five to four, as "four and a half to four and a half").

${ }^{85} 408$ U.S. at 710 (Powell, J., concurring).

${ }^{86} I d$.

${ }^{87}$ See, e.g., Storer Commc'ns, Inc. v. Giovan, 810 F.2d 580, 584-85 (6th Cir. 1987) (noting that several other circuits had based their support for a journalist's privilege at least partially on Justice Powell's concurrence); Fargo, supra note 13, at 430 (“[L] ower federal courts for the most part have interpreted Branzburg, because of Justice Powell's concurrence, as endorsing a First Amendment privilege against disclosure of confidential information in at least some proceedings.").

${ }^{88}$ STEPHEN BATES, THE REPORTER'S PRIVILEge, THEN AND NOW 5-6 (2000).

${ }^{89}$ Bob WOODWARD \& SCOTT ARMSTRONG, THE BRETHREN: INSIDE THE Supreme COURT 223 (1979). The notion that a Justice's concurrence can narrow the Court's holding is not unique. See, e.g., Brief of Appellants at 24-25, In re Grand Jury Subpoenas to Judith Miller, 397 F.3d 964 (D.C. Cir. 2005) (No. 04-3138) (quoting Justice Scalia for the proposition that a Justice who joins the majority in a 5-4 opinion, but writes a separate concurrence, can narrow the breadth of the majority's holding (citing McKoy v. North Carolina, 494 U.S. 433, 462 n.3 (1990) (Scalia, J., dissenting))). 
Justice Stewart's dissent ${ }^{90}$ argued for a qualified privilege for journalists. ${ }^{91}$ He argued that courts should employ a three-part test before ordering reporters to reveal confidences to a grand jury:

[T] he government must (1) show that there is probable cause to believe that the newsman has information that is clearly relevant to a specific probable violation of law; (2) demonstrate that the information sought cannot be obtained by alternative means less destructive of First Amendment rights; and (3) demonstrate a compelling and overriding interest in the information.

Most lower courts that have recognized a journalist's privilege have employed some variation of Justice Stewart's three-part test. ${ }^{93}$

Finally, Justice Douglas's dissent argued for an absolute privilege. ${ }^{94}$ Douglas said that his view of the First Amendment was close to Meiklejohn's, ${ }^{95}$ and that forcing a reporter to even appear before a grand jury would violate the precepts of the First Amendment. ${ }^{96}$

The outcome of Branzburg, then, was that a slim majority found no privilege, Justice Powell's concurrence seemingly limited the majority's holding, three Justices advocated a qualified privilege, and one Justice advocated an absolute privilege.

Fourteen years prior to Branzburg, then-Circuit Judge Stewart wrote the first federal court opinion that suggested recognition of a privilege for journalists based on the First Amendment. ${ }^{97}$ Garland $v$. Torre was a colorful dispute ${ }^{98}$ in which Judy Garland, in the course of her defamation suit against CBS, sought from reporter Marie Torre the identity of the source at CBS who allegedly made disparaging remarks about her. ${ }^{99}$ Judge Stewart, while recognizing that there could be cases in which a First Amendment-based privilege would protect

${ }^{90}$ Justice Stewart was joined by Justices Brennan and Marshall. Branzburg, 408 U.S. at 665 .

${ }^{91} I d$. at 725 (Stewart, J., dissenting).

${ }^{92}$ Id. at 743 (Stewart, J., dissenting).

${ }^{93}$ See James C. Goodale et al., Reporter's Privilege, in 3 COMmUniCATIONS LAW 404-06 $\&$ n.85 (PLI Commc'ns Law, Course Handbook Series 2004) (listing cases).

${ }^{94} 408$ U.S. at 712 (Douglas, J., dissenting).

${ }_{95} I d$. at 713-14. See supra Part I.A.4 for a discussion of the Meiklejohn view of the First Amendment.

${ }_{96}^{96} 408$ U.S. at 712.

${ }^{97}$ Garland v. Torre, 259 F.2d 545 (2d Cir. 1958). In fact, Justice Stewart first suggested his three-part test in this case. Id. at 549-50.

${ }^{98}$ For a first-person account of the ordeal (and its positive effect on the author's career as a journalist), see MARIE TORRE, DON'T QUOTE ME (1965).

${ }_{99} 259$ F.2d at 547. 
reporters, ${ }^{100}$ nevertheless held that the interests of the plaintiff in this case required disclosure. ${ }^{101}$

Today, the level of protection for journalists varies widely across the circuit courts of appeals, ${ }^{102}$ from a high level of protection in the Second and Ninth Circuits to no protection at all in the Sixth Circuit. The D.C. ${ }^{103}$ First, ${ }^{104}$ Second, ${ }^{105}$ Third,${ }^{106}$ Fourth, ${ }^{107}$ Fifth, ${ }^{108}$ Ninth,${ }^{109}$ Tenth, ${ }^{110}$ and Eleventh ${ }^{111}$ Circuits have all explicitly recognized the privilege. The Seventh Circuit has not ruled explicitly one way or the other, but has recently cast doubt on the existence of a federal journalist's privilege. ${ }^{112}$ The Eighth Circuit has not made a definitive rul-

$100 \quad$ Id. at 548.

101 Id. at 551.

102 See generally Goodale et al., supra note 93, at 431-573 (2004) (outlining in detail the case law in each circuit); Reporters Comm. for Freedom of the Press, The Reporter's Privilege, http://www.rcfp.org/privilege (last visited Sept. 20, 2005) (providing a comprehensive legal database for the specifics of the law of journalist's privilege in each circuit).

${ }^{103}$ See Zerilli v. Smith, 656 F.2d 705, 711 (D.C. Cir. 1981) ("[A] qualified privilege would be available in some circumstances even where a reporter is called before a grand jury to testify.").

104 See Bruno \& Stillman, Inc. v. Globe Newspaper Co., 633 F.2d 583, 594 (1st Cir. 1980) (finding support for a journalist's privilege from, inter alia, Branzburg, Herbert $v$. Lando, 441 U.S. 153, 176 (1979), FED. R. CIV. P. 26, and FED. R. EVID. 501).

${ }^{105}$ See United States v. Burke, 700 F.2d 70, 76-77 (2d Cir. 1983) (holding that Second Circuit law protects the interests of both reporters and the public in safeguarding journalists' sources, implementing Justice Stewart's three-part test for determination of the qualified journalist's privilege, and finding "no legally-principled reason for drawing a distinction between civil and criminal cases").

${ }^{106}$ See United States v. Cuthbertson, 630 F.2d 139, 146 (3d Cir. 1980) (" $[\mathrm{J}]$ ournalists have a federal common-law qualified privilege arising under Fed. R. Evid. 501 to refuse to divulge their confidential sources.”).

${ }^{107}$ See Ashcraft v. Conoco, Inc., 218 F.3d 282, 287 (4th Cir. 2000) ("News reporters are entitled to some constitutional protection of the confidentiality of [their] sources." (citing Pell v. Procunier, 417 U.S. 817, 834 (1974))).

108 See Miller v. Transamerican Press, Inc., 621 F.2d 721, 725 (5th Cir. 1980) ("We hold that a reporter has a First Amendment privilege which protects the refusal to disclose the identity of confidential informants, however, the privilege is not absolute ....").

${ }^{109}$ See Shoen v. Shoen, 5 F.3d 1289, 1292 (9th Cir. 1993) ("[W]hen facts acquired by a journalist in the course of gathering the news become the target of discovery, a qualified privilege against compelled disclosure comes into play.").

${ }^{110}$ See Silkwood v. Kerr-McGee Corp., 563 F.2d 433, 437 (10th Cir. 1977) (“[T]he [journalist's] privilege is no longer in doubt.").

${ }^{111}$ See United States v. Caporale, 806 F.2d 1487, 1504 (11th Cir. 1986) (adopting Justice Stewart's three-part test for a qualified journalist's privilege).

112 See McKevitt v. Pallasch, 339 F.3d 530, 533 (7th Cir. 2003) (arguing that courts recognizing a privilege for nonconfidential information "may be skating on thin ice"). 
ing, ${ }^{113}$ but district courts in the circuit have recognized the privilege. ${ }^{114}$ Only the Sixth Circuit has explicitly denied the privilege's existence ${ }^{115}$ (and even district courts in the Sixth Circuit have acknowledged the privilege. $)^{116}$

\section{B. States'Actions}

The Supreme Court in Branzburg invited state legislatures to enact their own journalist's privilege laws. ${ }^{117}$ At the time of the decision, seventeen states had already done so ${ }^{118}$ today, thirty-two states ${ }^{119}$ have shield laws. ${ }^{120}$ California has even added protection for journalists to

${ }^{113}$ See In re Grand Jury Subpoena Duces Tecum, 112 F.3d 910, 918 n.8 (8th Cir. 1997) (noting that the question of a "qualified news reporter's privilege . . is an open one in this Circuit").

${ }^{114}$ See, e.g., Richardson v. Sugg, 220 F.R.D. 343, 347 (E.D. Ark. 2004) (“[There is] a First Amendment qualified reporter's privilege in civil cases against compelled disclosure of the identity of the reporter's confidential sources and of information, both confidential and nonconfidential, gathered by the reporter in the news gathering process.").

${ }^{115}$ See Storer Commc'ns, Inc. v. Giovan, 810 F.2d 580, 584 (6th Cir. 1987) (“[W]e decline to join some other circuit courts ... [that have] adopted the qualified privilege balancing process urged by the three Branzburg dissenters and rejected by the majority."). The court disagreed with (and openly criticized) the other circuits' reading of Justice Powell's concurrence as limiting the majority opinion, and Justice Stewart's dissent as supplying a three-part balancing test. Id. "The Constitution does not, as it never has, exempt the newsman from performing the citizen's normal duty of appearing and furnishing information relevant to the grand jury's task." Id. at 583 (quoting Branzburg, 408 U.S. at 691).

${ }^{116}$ See, e.g., Southwell v. S. Poverty Law Ctr., 949 F. Supp. 1303, 1312 (W.D. Mich. 1996) (finding a qualified reporter's privilege).

${ }_{117}$ See Branzburg, 408 U.S. at 706 (stating the Court's desire to leave "state legislatures free ... to fashion their own standards"). law).

${ }^{118}$ See id. at 690 n.27 (listing the states that had enacted a journalist's privilege

${ }^{119}$ References herein to "states" will include the District of Columbia (which has a shield law).

${ }^{120}$ Ala. CODE $\S 12-21-142$ (1995); Alaska STAT. $\$$ 09.25.300-.390 (2004); ARIZ. REv. STAT. ANN. \$§ 12-2214, 12-2237 (2003); ARK. CODE ANN. \$ 16-85-510 (1987); CAL. Evid. CODE $§ 1070$ (West 1995) and CAL. CIV. Proc. CODE $§ 1986.1$ (West 1998); COLO. REV. STAT. § 13-90-119 (2004); DEL. CODE ANN. tit. 10, §§ 4320-4326 (1999); D.C. CODE ANN. $\S \S 16-4701$ to -4704 (LexisNexis 2005); FLA. STAT. ANN. $§ 90.5015$ (West 1999); GA. CODE ANN. § 24-9-30 (1995 \& Supp. 2005); 735 ILL. Comp. STAT. ANN. 5/8-901 to -909 (West 2002); IND. CODE ANN. § 34-46-4-1 (West 1999); Ky. REv. STAT. ANN. § 421.100 (LexisNexis 1992); LA. REV. STAT. ANN. \$§ 45:1451-1459 (1999); Md. Code AnN., CTs. \& JUd. Proc. § 9-112 (LexisNexis 2002); MiCh. Comp. LAWS ANN. $\S 767.5 \mathrm{a}$ (West 2000); MINN. STAT. ANN. $\$ 5595.021$ to 595.025 (West 2000); MonT. CODE ANN. §§ 21-1-901 to -903 (2003); NEB. REV. STAT. \$§ 20-144 to -147 (1997); NEV. REv. STAT. ANN. §§ 49.275, 49.385 (LexisNexis 2002); N.J. STAT. ANN. § 2A:84A-21 (West 1994); N.M. STAT. ANN. §38-6-7 (LexisNexis 1998); N.Y. CIV. RIGHTS LAW § 79-h 
its constitution. ${ }^{121}$ In addition, two state supreme courts have created such privileges, based on their interpretations of the evolving common law. ${ }^{122}$ Courts in every other remaining state ${ }^{123}$ (save Wyoming $^{124}$ ) have recognized some form of the privilege.

(McKinney 1992); N.C. GEN. STAT § 8-53.11 (2003); N.D. CENT. CODE § 31-01-06.2 (1996); OHIO REV. CODE ANN. $\$ \S 2739.04$, 2739.12 (LexisNexis 2000); OKLA. STAT. tit. 12, § 2506 (2001); OR. REV. STAT. \$§ 44.510-.540 (2003); 42 PA. CONS. STAT. § 5942 (2002); R.I. GEN. LAWS $§ \S 9-19.1-1$ to -3 (1995); S.C. CODE ANN. § 19-11-100 (2004); TENn. Code. ANN. § 24-1-208 (2000). Guam has also enacted a shield law. GUAm CODE ANN. tit. 6, §9101 (1993).

${ }^{121}$ CAL. CONST. art. 1, § 2(b).

${ }^{122}$ See In re John Doe Grand Jury Investigation, 574 N.E.2d 373, 375-77 (Mass. 1991) (recognizing a journalist's privilege, grounded in the common law, for criminal grand juries); Sinnott v. Boston Ret. Bd., 524 N.E.2d 100, 103-04 (Mass. 1988) (recognizing a journalist's privilege, grounded in the common law, for civil actions); Senear v. Daily Journal-Am., 641 P.2d 1180, 1183 (Wash. 1982) (finding a rebuttable common law privilege).

${ }^{123}$ The following cases, drawn from state appellate courts, have recognized the privilege: Conn. State Bd. of Labor Relations v. Fagin, 370 A.2d 1095, 1097 (Conn. Super. Ct. 1976) (“[T] he public interest in non-disclosure of a journalist's confidential sources [sometimes] outweighs the public and private interest in compelled testimony." (internal quotation marks omitted) (quoting Baker v. F\&F Inv., 470 F.2d 778, 783 (2d Cir. 1972)); State v. Salsbury, 924 P.2d 208, 213 (Idaho 1996) (establishing a balancing test for a qualified reporter's privilege); Winegard v. Oxberger, 258 N.W.2d 847,850 (Iowa 1977) ("[T] his court is persuaded there exists a [limited] fundamental newsperson privilege....”); State v. Sandstrom, 581 P.2d 812, 814 (Kan. 1978) (“[A] newsperson has a limited privilege of confidentiality ...."); In re Letellier, 578 A.2d 722, 726 (Me. 1990) (requiring a "balance between societal and constitutional interests"); Classic III, Inc. v. Ely, 954 S.W.2d 650, 655 (Mo. Ct. App. 1997) (adopting a balancing test for journalist's privilege); Opinion of the Justices, 373 A.2d 644, 647 (N.H. 1977) (finding a qualified privilege based on the state constitution); Hopewell v. Midcontinent Broad. Corp., 538 N.W.2d 780, 782 (S.D. 1995) ("[W]e hold that a 'qualified privilege' protects confidential news sources from disclosure under certain circumstances."); Channel Two Television v. Dickerson, 725 S.W.2d 470, 471 (Tex. App. 1987) (recognizing a qualified reporter's privilege); State v. Gundlah, 624 A.2d 368, 369 (Vt. 1993) (holding that a reporter had a "colorable constitutional claim" to a journalist's privilege, even though the case was moot); Brown v. Commonwealth, 204 S.E.2d 429, 431 (Va. 1974) (finding a privilege related to the First Amendment); State ex rel. Charleston Mail Ass'n v. Ranson, 488 S.E.2d 5, 10 (W. Va. 1997) (“[A] reportorial privilege exists in West Virginia.”); Zelenka v. State, 266 N.W.2d 279, 286 (Wis. 1978) ("[A] journalist ha[s] a constitutionally based privilege to refuse to disclose sources of information received in confidence...." (citing State v. Knops, 183 N.W.2d 93, 99 (Wis. 1970))).

Appellate courts in Hawaii, Mississippi, and Utah have not been presented with the issue since Branzburg, but federal district courts in these states, relying on their interpretation of each state's law, have found the privilege. See DeRoburt v. Gannett Co., 507 F. Supp. 880, 883 (D. Haw. 1981) ("First Amendment protection of a free press underlies the newsman's privilege to refuse to reveal news sources under certain circumstances ....”); Brinston v. Dunn, 919 F. Supp. 240, 242 (S.D. Miss. 1996) (assuming Mississippi courts would employ Justice Stewart's three-part test); Bottomly v. Leu- 
The scope of protection afforded by state shield law varies widely among the states. ${ }^{125}$ Indeed, one analysis of each state's shield law found the differences to be enormous, ranging from protecting all information (including eyewitness accounts and non-confidential information) to protecting identities of sources only, from protecting all proceedings to protecting only adjudicative court proceedings, from granting an absolute privilege to granting a qualified privilege, and finally requiring widely varying levels of proof from a party seeking the information. ${ }^{126}$

\section{Foreign Jurisdictions' Treatment}

Several foreign common law jurisdictions have also recognized a privilege for journalists. ${ }^{127}$ While the United States is certainly not bound by such decisions, foreign courts' decisions do carry persuasive weight when their reasoning is sound. ${ }^{128}$

cadia Nat'l Corp., 24 Media L. Rep. (BNA) 2118, 2119-20 (D. Utah 1996) (using a balancing test for a qualified journalist's privilege).

${ }^{124}$ Wyoming courts, state and federal, as far my research has shown, have never been presented with the issue.

${ }^{125}$ See Alexander \& Cooper, supra note 67, at 55 ("There was no language [in shield laws] that was common across the states.").

${ }^{126} I d$. at 61-64, tbls.1, 2, 3, \& 4 .

${ }^{127}$ For an overview of several countries' approaches to privileges for journalists, see International CENTRE AgAinst CENSORShip, The ARTiCle 19 FreEDOM OF EXPRESSION HANDBOOK: INTERNATIONAL AND COMPARATIVE LAW, STANDARDS AND PROCEDURES (1993).

${ }^{128}$ For recent examples of the Supreme Court looking abroad for guidance, see Roper v. Simmons, 125 S. Ct. 1183, 1200 (2005) ("It is proper that we acknowledge the overwhelming weight of international opinion ...."); Lawrence v. Texas, 539 U.S. 558, 573 (2003) (looking to the European Court of Human Rights and the European Convention on Human Rights for guidance); see also Charles Lane, The Court is Open for Discussion: AU Students Get Rare Look at Justices' Legal Sparring, WASH. POST, Jan. 14, 2005, at A1 (attributing to Justice Breyer the "idea that the Supreme Court needs to take greater notice of the legal opinions abroad"). However, not all members of the Court are in favor of using foreign courts' rationales in deciding U.S. cases. See, e.g., Lawrence, 539 U.S. at 598 (Scalia, J., dissenting) ("The Court's discussion of these foreign views ... [is] meaningless dicta.”); Foster v. Florida, 537 U.S. 990, 991 n.* (2002) (Thomas, J., concurring in denial of certiorari) ("[T]his Court[] . . should not impose foreign moods, fads, or fashions on Americans."); see also Lane, supra, at A1 (attributing to Justice Scalia the idea that "the framers of the U.S. Constitution "would be appalled' to see the document they wrote interpreted in light of the views of European courts"). For a fine discussion of the current effect of foreign judgments on American jurisprudence, see Harold Hongju Koh, International Law as Part of Our Law, 98 AM. J. INT'L L. 43 (2004). 
The European Court of Human Rights has held that journalists have a privilege to refuse to disclose their confidential sources. ${ }^{129}$ To overcome the privilege, the government must show "an overriding requirement in the public interest." ${ }^{130}$ This can be accomplished only by proving (1) "'necessity' for any restriction on freedom of expression," and (2) proportionality "to the legitimate aim pursued." ${ }^{131}$ After noting that "freedom of expression constitutes one of the essential foundations of democratic society," the court held that journalists' "watchdog" function would be seriously undermined if they were compelled to disclose information given them in confidence. ${ }^{132}$ The court was particularly concerned with the "chilling effect" of requiring journalists to disclose their confidential sources. ${ }^{133}$

The New Zealand Court of Appeal similarly held that under the common law "newspaper rule," the press (both print and broadcast) is protected from disclosing the source of confidential information. ${ }^{134}$ Noting the "public interest in the dissemination of information," the court held that the rule applies pretrial as well as at trial, and in actions for libel as well as actions in which the reporter is not a party. ${ }^{135}$ The court set a very high threshold for piercing the privilege: "The rule is one to be applied by the Courts as a matter of course except where special circumstances are established warranting a departure from it." ${ }^{136}$ As support for its holding that a democratic society demands high protection for the press, the court cited several English, Australian, and New Zealand cases sustaining the theory underlying the "newspaper rule": that the public interest in a free press demands that journalists be given a privilege to refuse to identify the sources of confidential information. ${ }^{13}$

In Canada, Ontario's highest court established a journalist's privilege in $2004 .^{138}$ The court noted that the "law of privilege may evolve

${ }^{129}$ See Goodwin v. United Kingdom (No. 7), 1996-II Eur. Ct. H.R. 483, 500 (citing the role of an independent press as a governmental watchdog, inter alia, as grounds for finding a rebuttable journalist's privilege).

${ }^{130}$ Id.

${ }^{131} I d$.

${ }^{132} I d$.

${ }^{133} I d$.

${ }^{134}$ Broad. Corp. of N.Z. v. Alex Harvey Indus., Ltd., [1980] 1 N.Z.L.R. 163 (C.A.), 163.

${ }^{135} I d$.

${ }^{136} \mathrm{Id}$.

${ }^{137} I d$. at $170-71$

${ }^{138}$ R. v. Nat'l Post, 69 O.R.3d 427, If 82 (Ontario 2004) (Can.). 
to reflect the social and legal realities of our time."139 Interestingly, though most commentators cite Wigmore for the proposition that journalists should not be afforded a privilege, ${ }^{140}$ the Ontario court used Wigmore's four criteria to find "an overwhelming interest in protecting the identity" of confidential sources. ${ }^{141}$ The court outlined a balancing test for lower courts to use when determining when the interests of society are best served by compelling testimony from reporters. ${ }^{142}$

Decisions from Canada and New Zealand, jurisdictions both based on the same English common law as the United States, should carry persuasive weight with our courts, ${ }^{143}$ especially considering that the United States holds itself up as a world leader in terms of protecting press freedoms. ${ }^{144}$ Similarly, American courts should take note that Article Ten of the European Convention on Human Rights, ${ }^{145}$ which protects "freedom of expression" (similar to the U.S. Constitution's First Amendment), was interpreted by Europe's high court as granting a privilege to journalists. ${ }^{146}$

${ }^{139}$ Id. If 58 (internal quotations omitted) (emphasis added).

${ }^{140}$ See supra Part I.B (noting Wigmore's opposition to the journalist's privilege).

${ }^{141}$ Nat'l Post, 69 O.R.3d, II 78.

${ }^{142}$ Id. I 82.

${ }^{143}$ See supra note 128 for a discussion of international law's impact on American law.

${ }^{144}$ See Kim R. Holmes, Assistant Sec'y for Bureau of Int'l Org. Affairs, U.S. Dep't of State, Remarks to the World Press Freedom Committee and Communications Media Committee of the Association of the Bar of the City of New York (June 27, 2003), available at http://www.state.gov/p/io/rls/rm/2003/22115.htm (contrasting the United States' open stance toward the press with other countries' "repressi[ve]" stances by stating "the U.S. Government . . . is committed to strengthening the role of free media in society. Press freedom and access to information is so vitally important to developing democracies"); Stephan Minikes, U.S. Permanent Rep., Org. for Sec. and Cooperation in Europe, Statement to the Permanent Council (July 14, 2005), available at http://www.usembassy.it/file2005_07/alia/a5071809.htm ("The United States has the strongest freedom of expression protections in the world. ... Freedom of the press ... is protected under U.S. law to a significantly greater degree than is provided for in the International Covenant on Civil and Political Rights.").

${ }^{145}$ Convention for the Protection of Human Rights and Fundamental Freedoms art. 10, I 1, Nov. 4, 1950, Europ. T.S. No. 5 ("Everyone has the right to freedom of expression. This right shall include freedom to hold opinions and to receive and impart information and ideas without interference by public authority and regardless of frontiers.").

${ }^{46}$ See Goodwin v. United Kingdom (No. 7), 1996-II Eur. Ct. H.R. 483, 502 (holding that ordering the disclosure of a journalist's sources would be incompatible with Article 10 absent a "reasonable relationship of proportionality between the legitimate aim pursued by the disclosure order and the means deployed to achieve that aim"). 


\section{Other Sources of the Privilege}

In addition to federal courts, state courts, and state legislatures, there are several other sources that affect the law of journalist's privilege.

First, Congress has repeatedly considered enacting a federal shield law, ${ }^{147}$ and held numerous hearings on the issue in the early 1970 s in the wake of Branzburg. ${ }^{18}$ Though none of these bills has been successful, ${ }^{149}$ their existence and support from several legislators is telling. ${ }^{150}$

${ }^{147}$ The first such bill was introduced by Senator Arthur Capper in 1929. CHARLES W. WHALEN, JR., YOUR Right TO KNOW 175 (1973). The most recent bills were introduced by Sen. Richard Lugar in the Senate and Rep. Michael Pence in the House, both on July 18, 2005. See Free Flow of Information Act of 2005, S. 1419, 109th Cong. (2005) (seeking to "maintain the free flow of information to the public by providing conditions for the federally compelled disclosure of information by certain persons connected with the news media"); Free Flow of Information Act of 2005, H.R. 3323, 109th Cong. (2005) (setting forth the same mission). These bills joined a Senate bill currently pending that was introduced by Sen. Christopher Dodd, Free Speech Protection Act of 2005, S. 369, 109th Cong. (2005), a Senate bill currently pending with four bipartisan co-sponsors, Free Flow of Information Act of 2005, S. 340, 109th Cong. (2005), and a House bill with nine bipartisan co-sponsors, Free Flow of Information Act of 2005, H.R. 581, 109th Cong. (2005). Indeed, immediately following Branzburg, no fewer than forty-six separate bills relating to a journalist's privilege were introduced in Congress. VAN GERPEN, supra note 6, at 155 n.46.

${ }^{148}$ See, e.g., Hearings on Newsmen's Privilege Before the Subcomm. on Constitutional Rights of the S. Comm. on the Judiciary, 93d Cong. 383 (1973) (statement of Benno Schmidt, Jr., Professor of Law, Columbia Univ. Law Sch.) (addressing the government's ability to establish a journalist's privilege); Hearings Before Subcomm. No. 3 of the H. Comm. on the Judiciary, 92d Cong. 146 (1972) (testimony of Rep. Charles W. Whalen, Jr.) (evaluating the relationship between the press and the government); Hearings on Freedom of the Press Before the Subcomm. on Constitutional Rights of the S. Judiciary Comm., 92d Cong. 18-23 (1971-1972) (testimony of Harding F. Bancroft, Executive Vice President, N.Y. Times) (analyzing the ability and need for the government to establish the journalist's privilege). One congressional committee even produced a lengthy report on the issue. See Staff of Subcomm. on Administrative Practice And Procedure to the S. Comm. ON The Judiciary, 89Th CONG., The Newsman's Privilege 1 (Comm. Print 1966) (explaining past efforts at establishing a journalist's privilege).

In addition, two congressmen have chronicled their experiences in trying to pass a journalist's privilege bill through his respective chamber. See WHALEN, supra note 147, at 175 (Rep. Whalen) (detailing congressional attempts to establish a journalist's privilege); Sam J. Ervin, Jr., In Pursuit of a Press Privilege, 11 HARV. J. ON LEGIS. 233, 23341 (1974) (Sen. Ervin) (tracing the history of the press privilege issue from 1722 to the author's attempts to pass press privilege legislation in the 1970s).

${ }^{149}$ The current bills pending before Congress, though enjoying bipartisan support, are likely doomed to the same fate, mostly because they are opposed by the Justice Department and the Bush Administration and their enactment will not win members of Congress any political points. See Lorne Manly, Bill to Shield Journalists Gets Senate Panel Hearing, N.Y. TIMES, July 21, 2005, at A13 (noting that a scholar on congressional voting "did not sense deep support" for the bill). For an interesting first- 
A federal shield law has the benefit of adding a degree of certainty to the process, ${ }^{151}$ and is favored by some commentators who believe that judges are too self-interested in opposing the privilege to see its larger benefit to society. ${ }^{152}$

Aside from the issues associated with a state shield law, ${ }^{153}$ a federal shield law has the added complication of its interaction with state laws. While state shield laws sometimes apply in federal court ${ }^{154}$ (in diversity suits and in suits based on supplemental jurisdiction), ${ }^{155}$ there is de-

person account of the dénouement of federal action on the issue in 1973, see Ervin, supra note 148 , at $270-75$.

${ }^{150}$ However, some commentators argue that if Congress has considered and rejected the idea of passing a particular piece of legislation, courts should infer that Congress decided that the legislation was undesirable. See, e.g., Laurence H. Tribe, Toward a Syntax of the Unsaid: Construing the Sounds of Congressional and Constitutional Silence, 57 IND. L.J. 515, 529-30 (1982) (attributing at least some meaning to Congress's inaction on a particular issue). However, there are several reasons that Congress might stop consideration of a bill-legislative inertia being the most apparent-that do not evidence Congress's particular intent. See generally William N. ESKRIDGE, JR. \& Philip P. FRICKEY, CASES AND MATERIALS ON LEgislation: STATUTES AND THE CREATION OF PUBLIC POLICY 766, 772 (1988) (identifying the causes of congressional inaction); William N. Eskridge, Jr., Patterson v. McLean: Interpreting Legislative Inaction, 87 MiCH. L. REV. 67, 69 (1988) (identifying three situations where congressional inaction can be interpreted as meaningful).

${ }^{151}$ See infra Part III.B for a discussion of the need for certainty in the area of journalist's privilege.

${ }^{152}$ See VAN GERPEN, supra note 6, at 145 (noting that judges often act to preserve their own myopic interest of orderly courtroom management). But cf. Lewis H. Lapham, The Temptations of a Sacred Cow, HARPER's, Aug. 1973, at 43, 43 (remarking that having congressmen craft the dimensions of a journalist's privilege is akin to having "convicts building gallows from which they will hang," and, thus, Congress will fare no better at constructing the privilege).

${ }^{153}$ See supra Part II.B for a discussion of state shield laws.

${ }^{154}$ See FED. R. EvID. 501 (“[I]n civil actions and proceedings, with respect to an element of a claim or defense as to which State law supplies the rule of decision, the privilege of a witness ... shall be determined in accordance with State law."). The process is reciprocal: federal courts do not apply state shield laws if the case is predicated on a federal question. See, e.g., In re Grand Jury Proceedings, 867 F.2d 562, 564 (9th Cir. 1989) ("[F] ederal privilege law, not state law, must be applied in criminal cases brought in federal court.”); In re Am. Broad. Cos., 947 F. Supp. 1314, 1321 (E.D. Ark. 1996) (denying the news media organization's state shield law-based claim of a journalist's privilege "since state law privileges do not apply to a federal grand jury subpoena").

For a novel argument that Congress should incorporate state law privileges into federal cases, see Theodore Campagnolo, The Conflict Between State Press Shield Laws and Federal Criminal Proceedings: The Rule 501 Blues, 38 GONZ. L. REV. 445, 447 (2002) ("Congress should provide an exception to Rule 501 that would allow a reporter's privilege in the forum state to apply in federal grand jury proceedings and criminal cases, just as it would in civil diversity cases.").

${ }^{155}$ For rules on when a suit is subject to diversity or supplemental jurisdiction, see 28 U.S.C. $\$ \S 1332,1367$ (2000). 
bate over whether the federal government has the power to force a federal shield law on state courts, ${ }^{156}$ or whether the federal government should even try to do so. However, if federal law did not preempt the states' laws, then the benefits of uniformity would not be realized.

Congress has passed one law that touches on the issue of the journalist's privilege, evidencing at least its support for the cause. In the Privacy Protection Act of $1980,{ }^{157}$ which was passed in response to the Court's decision in Zurcher v. Stanford Daily, ${ }^{158}$ Congress protected news organizations' places of business from search warrants. ${ }^{159}$ However, while preventing law enforcement from casually searching a newsroom, the law has no bearing on the organization's duty to provide the evidence as a result of a subpoena.

The most influential federal source on the subject is the Attorney General's Guidelines for Subpoenas to the News Media, ${ }^{160}$ promulgated by Attorney General John Mitchell in 1970 in response to press uproar surrounding callous prosecutorial subpoenas. ${ }^{161}$ The Guidelines require the Attorney General to personally sign off on any subpoena to the press and note the Justice Department's policy of only

${ }^{156}$ See Anthony J. Bellia Jr., State Courts and the Making of Federal Common Law, 153 U. PA. L. REV. 825, 875 (2005) (noting the unsettled question of "whether congressional delegations of legislative power to state courts"-i.e., asking state courts to interpret and make federal common law with respect to privileges-"would be unconstitutional acts of commandeering state institutions or unconstitutional delegations of federal legislative power to state institutions"); Mark Neubauer, Comment, The Newsman's Privilege After Branzburg: The Case for a Federal Shield Law, 24 UCLA L. REV. 160, 187-88 (1976) (arguing that a federal shield law that forces federal evidentiary rules on state courts would have to be implemented under either Congress's power to regulate interstate commerce or its enforcement powers under the Fourteenth Amendment).

${ }^{157} 42$ U.S.C. $\$ 2000$ aa (2000).

${ }^{158} 436$ U.S. 547 (1978) (holding that police can execute a search warrant on a news outlet consistent with the First and Fourth Amendments).

${ }^{159}$ See 2 Rodney A. SMOlla, SMOlla AND Nimmer on Freedom OF SPEech § 25:32, at $52 \mathrm{n} .2$ (2005) (noting that the Act limits the situations in which government officers may search for journalists" "work products" or "documentary materials").

16028 C.F.R. $\$ 50.10$ (2004).

${ }^{161}$ For an account of Attorney General Mitchell's reasoning behind the Guidelines, see John Mitchell, Free Press and Fair Trial: The Subpoena Controversy, 59 ILL. B.J. 282, 283 (1970) (attempting to balance "the two great rights in conflict": the guarantee of freedom of the press and the right to a fair trial).

The Attorney General's Guidelines were not well received by commentators at the time, who accused the Department of Justice of trying to shield itself from criticism. WRIGHT \& GRAHAM, supra note 50, § 5426, at 739-40. One congressman even called them "laughable." Id. at 740 (citing Newsman's Privilege Act: Hearing on H.R. 837 Before Subcomm. No. 3 of the H. Comm. on the Judiciary, 92d Cong. 152 (1972)). 
issuing subpoenas when all other means of acquiring the information have failed. ${ }^{162}$ Note, though, that the Guidelines have no bearing on the actions of state prosecutors. The Supreme Court expressed its hope in Branzburg that the Guidelines "may prove wholly sufficient to resolve the bulk of disagreements and controversies between press and federal officials," ${ }^{163}$ but, as this Comment demonstrates, the problems between the press and government have only worsened, ${ }^{164}$ and the Guidelines have not stopped the proliferation of subpoenas. ${ }^{165}$ And, despite the Guidelines, the Justice Department does not support protections for journalists. ${ }^{166}$

Finally, opponents of the journalist's privilege argue that the federal rules of procedure provide adequate protection for journalists in complying with subpoenas. The rules allow courts to quash subpoenas in criminal trials if "compliance would be unreasonable or oppressive," 167 and in civil trials if they constitute "annoyance, embarrassment, oppression, or undue burden or expense." ${ }^{168}$ However, these rules were not crafted with the press in mind, and special accommodations must be made in order to respond to journalists' unique circumstances. This is not unlike Emerson's and Tribe's views that while the press should not get special protections, courts must still be cognizant of the press's unique role (and responsibilities and limitations). ${ }^{169}$

16228 C.F.R. $§ 50.10$ (2004). For a critique of the Guidelines, see VAN GERPEN, supra note 6 , at 72-73 (questioning the effectiveness of administrative guidelines, which can be altered "by the stroke of a pen"); see also BATES, supra note 7, at 4 (noting pessimistically that journalists' protection under the Guidelines "depend[s] on who holds office as Attorney General").

${ }^{163}$ Branzburg v. Hayes, 408 U.S. 665, 707 (1972).

${ }^{164}$ See infra Part III.C (discussing how the relationship between the media and the government has become more adversarial than in the past).

${ }^{165}$ See infra Part III.A.1 (noting that subpoenas to the press are more prevalent today than they were at the time that Branzburg was decided).

${ }^{166}$ See Reporters' Privilege Legislation: Issues and Implications: Hearing on S. 340 and H.R. 581 Before the S. Comm. on the Judiciary, 109th Cong. (July 20, 2005) (statement of James B. Comey, Deputy Att'y Gen.), available at http://www.cjog.net/documents/ James_Comey_testimony.pdf (calling a bill proposing a federal shield law "bad public policy" and noting the Justice Department's opposition to such privileges for journalists).

${ }^{167}$ FED. R. CRIM. P. 17 (c).

${ }^{168}$ FED. R. CIV. P. 26(c).

${ }^{169}$ See supra text accompanying notes 33-35 (describing Emerson's and Tribe's views on freedom of the press). 


\section{The NEED For A JOURNALIST's PRIVILEgE}

The nation's journalists today need a privilege more than they did thirty years ago and more than they did at the nation's founding. First, the number of subpoenas to news organizations is markedly increasing, ${ }^{170}$ underscoring the need for judicial imposition of restraint on prosecutors. Second, due to uncertainties in the law and the forum in which litigation might arise, ${ }^{171}$ reporters and sources are hardpressed to discern the strength of any promise of confidentiality. In addition, news organizations are increasingly becoming national in scale, leading to the growing hardship placed on reporters and editors (not to mention informants) of having to know the scope of any shield law or common law privilege in a particular state or circuit at a particular time. A pronouncement by the Supreme Court recognizing a uniform journalist's privilege will help alleviate this strain. Third, the media's relationship with the government has grown more adversarial, requiring the courts to place a check on the executive branch. Finally, courts are finding alarming numbers of journalists in contempt and ordering them to pay fines and even serve jail time, ${ }^{172}$ highlighting the need for judicial restraint in dealing with journalist's privilege cases.

\section{A. Subpoenas}

\section{The Prevalence of Subpoenas to the Press}

Subpoenas are more prevalent today than they were at the time Branzburg was decided. ${ }^{173}$ There are three interrelated reasons behind this phenomenon.

${ }^{170}$ See sources cited infra note 173 (showing the rise in press subpoenas).

${ }^{171}$ See Jane E. Kirtley, Branzburg v. Hayes Still Casts Uncertainty on Journalists' First Amendment Rights, Bulletin (Silha Ctr., Univ. of Minn., Minneapolis, Minn.), Summer 2004, at 1, 1, http://www.silha.umn.edu/Summer04/branzburg_v_hayes.pdf ("The result [of Branzburg] has been a crazy quilt of rulings which are often inconsistent and irreconcilable.").

${ }^{172}$ See infra note 216 (detailing the cases of reporters who have recently been jailed for contempt).

${ }^{173}$ Compare Achal Mehra, Newsmen's Privilege: An Empirical Study, 59 JOURN. Q. 560, 561 (1982) (finding that between 1960 and 1968 fewer than two subpoenas per year were served on reporters and that in 1982 the number was estimated to be at least 150), with AGENTS OF DISCOVERY, supra note 70, at 4 (finding that 823 subpoenas were served on the media in 2001). Statistically, both sources under-represent the actual number of subpoenas. Mehra relies on reported cases (and therefore cannot account 
First, prosecutors have become reluctant to perform their own investigations (whether because of the time, money, or effort involved), and have taken note that it is cheaper and sometimes just as effective to rely on the media for evidence. ${ }^{174}$ When prosecutors think they have a green light to use journalists' information, they do not hesitate to issue subpoenas. ${ }^{175}$ Journalists also receive more subpoenas than the average citizen because they are significantly better witnesses. ${ }^{176}$ Thirty-five years ago, the editors of the Columbia Journalism Review rhetorically questioned "whether American law enforcement agencies... have reached such a low state of efficiency that they cannot maintain their own surveillance of potentially dangerous organizations." ${ }^{177}$ That statement rings even more true today.

Second, video makes for exemplary courtroom evidence. Before television became as widespread as it is today, prosecutors who wanted to subpoena news outlets had to rely on reporters' first-person (and often second-person) accounts. Film can capture an event and freeze

for unreported cases), and Agents of Discovery uses a survey (and therefore cannot account for non-responsive survey recipients). But cf. Sherwood, supra note 59, at 120103 (attributing at least a partial rise in the number of subpoenas to the simple fact that the press and the government have assumed more antagonistic roles toward each other, so that while previously an informal request was met with an informal production of evidence, now a formal subpoena is needed).

${ }^{174}$ See Laurence B. Alexander et al., Branzburg v. Hayes Revisited: A Survey of Journalists Who Become Subpoena Targets, NEwSPAPER RES. J., Spring 1994, at 83, 95-97 (showing empirically that without the intervention of the courts (or legislature), prosecutors are more brazen about subpoenaing journalists for information); see also SMOLLA, supra note $159, \S 25: 34$, at 54 ("[A]t some point in the future, the government may abandon its tendency to tread lightly with requests for material from the media, and may begin to push aggressively for information."). But see Thomas C. Desmond, The Newsmen's Privilege Bill, 13 ALB. L. REV. 1, 8 (1949) (deeming claims by law enforcement officials that a reporter's privilege would interfere with criminal investigations as "groundless" because "surely the law enforcement officials, aided by staffs of trained technicians and armed with the latest weapons of science are in a better position to find a criminal than is a reporter").

${ }^{175}$ See Alexander et al., supra note 174, at 95-96 (finding that the number of prosecution subpoenas to the press markedly increased in the two years immediately following the Florida Supreme Court's limiting of the scope of the journalist's privilege in the state); Emerson, supra note 33, at 17 ("Following Branzburg the number of instances in which reporters were called upon to produce materials obtained in confidence greatly increased.").

${ }^{176}$ See Timothy L. Alger, Comment, Promises Not to Be Kept: The Illusory Newsgatherer's Privilege in California, 25 LOY. L.A. L. REv. 155, 167 (1991) ("Their practice of taking notes and photographs, their tendency to seek out controversies, and their independence of the disputing parties make journalists attractive and particularly credible witnesses.").

${ }^{177}$ Editorial, The Subpoena Dilemma, COLuM. JOuRn. REV., Spring 1970, at 2, 3. 
it in time. ${ }^{178}$ This phenomenon is borne out by statistics clearly showing that broadcasters receive far more subpoenas than newspapers. ${ }^{179}$ This imbalance exists in spite of the fact that print media are generally thought to be more focused on hard news than are broadcast media. Because newspapers perform more investigations and do more indepth reporting, it would logically follow that they would have more evidence potentially relevant to court proceedings. So why do they receive only a fraction of the number of subpoenas broadcasters do? In addition, the very nature of film evidence makes it susceptible to subpoenas under Justice Stewart's (and most lower courts') three-part test. ${ }^{180}$ By definition, a particular video clip is unavailable from another source because it is unique. ${ }^{181}$

Third, journalists are getting better at their jobs. The increasing institutionalization of the press, ${ }^{182}$ including the proliferation of both

${ }^{178}$ See Sherwood, supra note 59, at 1202 (noting that film is a very graphic embodiment of the evidence).

${ }^{179}$ See AgENTS OF DisCOVERY, supra note 70, at 1, 4 (finding that in $2001,79 \%$ of broadcasters received at least one subpoena while only $32 \%$ of newspapers did; in the same year, the average television station received 7.7 subpoenas, the average newspaper received 0.7 subpoenas); cf. L.A. Powe, Jr., "Or of the [Broadcast] Press," 55 TEx. L. REV. 39, 39 (1976) (arguing that the broadcast media should be protected to the same extent as the print media).

${ }^{180}$ See supra text accompanying notes 90-93 (discussing the three-part test from Justice Stewart's dissent in Branzburg).

${ }^{181}$ See Tuley, supra note 65, at 1827 (arguing that outtakes, because they "freeze" an event, can never be obtained from another source and therefore are particularly susceptible under the three-part test). Tuley also makes an interesting argument regarding judges' "subtle bias" favoring "traditional" work product (i.e., a reporter's notes) over newer work product (i.e., a camerawoman's video outtake). Id. at 1826. Judges might consider video outtakes not as editorial processes in need of First Amendment protection, but rather as mechanical recordings made without independent thought. Id. at 1836 . Whereas a reporter's personal handwritten notes involve a "trained eye and professional instincts" (and therefore receive more protection), outtakes may be thought of as "indiscriminately registered information." Id.

${ }^{182}$ See Fargo, supra note 13, at 82 (noting the "growing institutionalization of the press and its heightened influence and wealth" in the late nineteenth and early twentieth centuries). The press as an institution has certainly changed since 1868 , when Thomas Cooley wrote that a newspaper publisher occupied "the position in the courts that the village gossip and retailer of scandal occupied two hundred years ago, with no more privilege and no more protection." 2 THOMAS B. COOLEY, A TREATISE ON THE CONSTITUtional Limitations Which Rest UPON THE LEgislative POWER OF THE STATES OF THE AMERICAN UNION 938 (Walter Carrington ed., 8th ed. 1927) (1868).

Not all scholars think that the press has changed for the better. See, e.g., JAMES FALLOWS, BREAKING THE NEWS: HOW THE MEDIA UNDERMINE AMERICAN DEMOCRACY 150 (1996) (arguing that "[j] ournalism is not a 'profession"” because it does not require "fixed standards for admission and mastery over a specialized field of knowledge"); Carl T. Bogus, The Death of an Honorable Profession, 71 IND. L.J. 911, 937-38 
graduate and undergraduate programs, ${ }^{183}$ has led to higher standards in the profession.

New technologies, while aiding journalists in the course of their jobs, also aid government officials when they seek the fruits of journalists' work. ${ }^{184}$ Smolla argues that new technologies make information gathered by the press significantly more valuable to the government. ${ }^{185}$ As the press's newsgathering ability increases with new technological development, it will simply have more information of value. ${ }^{186}$ In addition, the quality of the information gathered (i.e., satellite pictures, videotape, sound recordings, etc.) will increase. ${ }^{187}$

While some commentators ascribe ulterior motives to lawenforcement officials who subpoena news organizations, ${ }^{188}$ others argue that prosecutors' increased usage of the subpoena to access journalists' materials reflects a changing media and investigative culture. ${ }^{189}$ Whatever the reasons behind the phenomenon, the evidence clearly shows that subpoenas to news organization are significantly more prevalent than they were at the time Branzburg was decided, ${ }^{190}$ and action by the courts is necessary to reverse this trend.

\section{The Problem with Targeting the Most Prominent Organizations}

The prevailing view among commentators is that a journalist's privilege is especially needed to protect small news outlets, which do not have the resources to constantly fight government subpoenas. ${ }^{191}$

(1996) (arguing that journalism is not a profession because both journalists, collectively, and the general public do not believe that a "professional attitude" pervades the field).

${ }^{183}$ See Bogus, supra note 182, at 933-34 (noting that today there are 414 journalism programs in the country, up from one in 1904, and that an "increasing number of journalists hold baccalaureate or master's degrees from schools of journalism”).

${ }^{184}$ For a novel argument as to why a court should not compel disclosure of a television station's files, see Gilbert v. Allied Chemical Corp., 411 F. Supp. 505 (E.D. Va. 1976) (denying a station operator's Fourteenth Amendment due process argument).

${ }^{185}$ SMOLLA, supra note $159, \S 25: 34$, at 54 .

${ }^{186} I d$.

${ }^{187} \mathrm{Id}$.

${ }^{188}$ See, e.g., Sherwood, supra note 59, at 1199 (“[P] utting a gag on the press may be as much an objective as eliciting information from it.”).

${ }^{189}$ See sources cited supra notes 176-183 and accompanying text.

${ }^{190}$ Not only are subpoenas more prevalent, but courts are finding against journalists at ever-increasing rates. See Schmid, supra note 51, at 84 (showing empirically that the success rates of three subpoenaing parties-criminal defendants, grand juries, and prosecutors-rose during the 1990s).

${ }^{191}$ See Wright \& GRAHAM, supra note 50, § 5426, at 752 (noting that less wellestablished news outlets arguably need more protection than the established press be- 
However, the privilege is also necessary for the large, prominent media organizations, which are constantly embroiled in court battles over government subpoenas. ${ }^{192}$ These large news organizations have the resources to conduct investigations into official wrongdoing and the wherewithal to disseminate their findings. Their stories are the most potentially damaging to the government, and arguably constitute the best journalism. The government sometimes targets these media outlets not to obtain the evidence for a court proceeding, but rather to track down a source that has acted against the government's interests. ${ }^{193}$ A journalist's privilege is therefore needed to protect not just the small news outlet that cannot protect itself, but also the large news organization that conducts the kind of journalism that the First Amendment was meant to protect.

\section{B. The Uncertain Nature of the Scope of the Law and the Forum in Which Litigation Might Arise}

A large part of a reporter's job is speaking with people who possess relevant information. Sometimes, due to the sensitive nature of certain issues, these people will not speak with a reporter unless their identity is kept confidential. A reporter's promise to keep a source's identity in confidence benefits all parties involved: the public receives

cause the established press has sufficient political power to fight government subpoenas); Hilden, supra note 55 ("[O]utside journalists-including bloggers-may be willing to take aim more quickly, speak more harshly, and investigate more thoroughly than insider journalists ...."). In addition, one can argue that established press organizations "often have ties to the local power structure that make them less willing to report ... on matters that reflect unfavorably on those who control the community." WRIGHT \& GRAHAM, supra note 50, § 5426, at 752.

${ }^{192}$ See, e.g., Reporters Comm. for Freedom of the Press, Reporters and Federal Subpoenas (July 7, 2005), http://www.rcfp.org/shields_and_subpoenas.html (identifying the news organizations currently embroiled in subpoena disputes, among them some of the most prominent national newspapers (New York Times, Washington Post, San Francisco Chronicle), wire services (Associated Press, Reuters), television networks (ABC, $\mathrm{CBS}$ ), cable networks (CNN), news magazines (Time), and radio networks (NPR)).

${ }^{193}$ In discussing this phenomenon, Van Gerpen asserts that

the information [sought in a subpoena to the press] has frequently not been employed for the correct disposal of litigation, but rather has been used to track down the originator of the embarrassing exposé. One might well question the appropriateness of the argument for the "law's right to everyman's evidence" by investigators who pursue source disclosure for the purpose of establishing a successful cover-up operation.

VAN GERPEN, supra note 6, at 12; see also Sherwood, supra note 59, at 1199 (noting that the government may be trying to elicit the names of a journalist's sources for ulterior motives). 
the pertinent information, the source does not face potential retribution or scorn at her job, and the reporter is able to do her job more effectively. The system unravels if the reporter is unable to keep her promise of confidentiality: specifically, future sources will not speak to that reporter; more generally, sources will be more reluctant to speak with reporters because they are worried that their identity will be made public. ${ }^{194}$ As a result, the public loses out because it will receive less relevant information with which to make informed opinions. ${ }^{195}$

When sources and reporters are uncertain as to whether the source's identity may be kept confidential, speech to reporters is necessarily chilled. And in today's highly politicized atmosphere, it is likely that the issue of a journalist's privilege will continue to arise in the context of administration leaks. ${ }^{196}$ Therefore, because of the patchwork of shield laws and privileges across the states and federal circuits, the increasing nationalization of media companies, and the uncertainty as to the forum in which litigation might arise, speech to reporters is being unnecessarily chilled. ${ }^{197}$

${ }^{194}$ See John E. Osborn, The Reporter's Confidentiality Privilege: Updating the Empirical Evidence After a Decade of Subpoenas, 17 Colum. HuM. RTS. L. REV. 57, $72-81$ (1985) (showing empirically that sources are more likely to speak with reporters when they are guaranteed confidentiality); see also WOODWARD, supra note 5, at 185 ("It is critical that confidential sources feel they would be protected for life."); Frank Rich, Op-Ed, We're Not in Watergate Anymore, N.Y. TIMES, July 10, 2005, § 4, at 12 (asking rhetorically, "What high-level source would risk talking to Time about governmental corruption after this cave-in?")

${ }^{195}$ See Comm. on Commc'ns \& Media Law, supra note 82, at 227 ("Without a reporter's ability to promise confidentiality, and keep that promise ... . [i]mportant information the public relies upon would simply dry up.").

${ }^{196}$ As Judge Tatel phrases it:

[G]iven the many leaks that no doubt occur in [Washington, D.C.,] every day, it would be naïve to suppose that [this] will be the last [case raising the issue of the journalist's privilege]. For the sake of reporters and sources whom such litigation may ensnare, we should take this opportunity to clarify the rules governing their relationship.

In re Grand Jury Subpoena, Judith Miller, 397 F.3d 964, 990 (D.C. Cir.) (Tatel, J., concurring), cert. denied, 125 S. Ct. 2977 (2005).

${ }^{197}$ See Jaffee v. Redmond, 518 U.S. 1, 18 (1996) ("[I]f the purpose of the privilege is to be served, the participants in the confidential conversation 'must be able to predict with some degree of certainty whether particular discussions will be protected. An uncertain privilege ... is little better than no privilege at all."' (quoting Upjohn Co. v. United States, 449 U.S. 383, 393 (1981))). As a testament to the disagreement among judges-let alone reporters or sources-on the issue, see the majority opinion in Judith Miller:

The Court is not of one mind on the existence of a common law privilege.

Judge Sentelle would hold that there is no such common law privilege for rea- 
News organizations today are larger and more complex than they were thirty years ago. The rise of media conglomerates has transformed the media landscape from one of small independent organizations to one of large national corporations. ${ }^{198}$ The larger the conglomerate, the more likely that it is run by a businessperson, not a professional journalist, and therefore the more likely that it will quickly and cheaply accede to subpoena demands. ${ }^{199}$ While this policy of capitulation may be good for business, it is devastating to the role of journalists and the safeguards of the First Amendment. ${ }^{200}$

sons set forth in a separate opinion. Judge Tatel would hold that there is such a common law privilege. Judge Henderson believes that we need not, and therefore should not, reach that question.

397 F.3d at 973 .

${ }^{198}$ See, e.g., Ben H. Bagdikian, The New Media Monopoly 27-54 (2004) (arguing that five conglomerates-Disney, General Electric, News Corp., Time Warner, and Viacom-control the vast majority of the media industry); Columbia Journalism Review, Who Owns What?, http://www.cjr.org/tools/owners/ (last visited Sept. 20, 2005) (compiling a database of the current media conglomerates and their holdings).

${ }^{199}$ See Alan M. Adelson, Have the News Media Become Too Big to Fight?, SATURDAY REV., Mar. 14, 1970, at 106 (arguing that corporate leaders, who are often more concerned with the company's bottom line than journalistic rights, often readily comply with a government subpoena instead of spending the time and money to fight it). Adelson made his point thirty-five years ago; today, with only five companies owning the lion's share of the media market, the sentiment rings even truer.

The Valerie Plame case offers a ready example. After initially resisting the government's subpoenas, Time magazine, which is a major subsidiary of Time Warner, one of the Big Five media companies, agreed to turn over reporter Matt Cooper's notes. On the other hand, the New York Times, which, while admittedly large, is focused primarily on journalism, continued to refuse to comply with the government's requests, and journalist Judith Miller was sent to jail. See Leonnig, supra note 50, at A2 (reporting that if Time continued to refuse to turn over Matt Cooper's notes, Chief Judge Hogan would "assess a retroactive fine of $\$ 270,000$, which he said reflects the wealth of the magazine's corporate owner, Time Warner"); $i d$. (noting that while Cooper, the journalist, would prefer that his notes not be turned over, he recognized that Time, his employer, "had its own obligations to consider"); Rich, supra note 194, § 4, at 12 (arguing that media conglomerate Time Warner's "corporate mentality" motivated Time Editorin-Chief Norman Pearlstine's decision to turn over Matt Cooper's notes and derisively noting that Pearlstine is a member of the board of the Committee to Protect Journalists).

${ }^{200}$ See David A. Logan, Of "Sloppy Journalism," “Corporate Tyranny," and Mea Culpas: The Curious Case of Moldea v. New York Times, 37 WM. \& MARY L. REv. 161-62 (1995) (pointing out that in today's society, free speech law is often made by powerful corporations with economic interests foremost in mind, rather than by a lonely pamphleteer taking on the government for a principled cause); $c$. Rich, supra note 194, § 4, at 12 (referring to Time's acquiescence in turning over Matt Cooper's notes to Special Counsel Fitzgerald as "buckl[ing]"). But cf. VAN GERPEN, supra note 6, at 28 ("[I]t is likely that a more deferential press would encourage even more subpoenas."). 
The editors and managers of these organizations have a vested interest in keeping their reporters out of court. ${ }^{201}$ To this end, they can develop a working knowledge of the intricacies of the relevant laws in each state. ${ }^{202}$ However, it is expensive and time-consuming to gather this information, not to mention almost impossible for reporters to absorb it sufficiently before talking with sources in several different areas of the country. If the law of journalist's privilege were uniform throughout the country, news organizations would not face these burdensome costs. The law in this field as it stands today is at the height of uncertainty, ${ }^{203}$ for reporters cannot be sure which jurisdiction will subpoena them, and therefore cannot guarantee confidentiality to their sources. ${ }^{204}$

${ }^{201}$ One of the traditional arguments for a journalist's privilege is that responding to subpoenas is unduly time-consuming and costly, especially because "reporters are more susceptible to being subpoenaed than are other professionals." WRIGHT \& GRAHAM, supra note $50, \S 5426$, at 721 .

In response to the burden of responding to and fighting many subpoenas, some news organizations have instituted policies to quickly destroy potential evidence. See AGENTS OF DISCOVERY, supra note 70, at 4 ("Several surveyed newsrooms reported the institution of policies to destroy raw footage or reporters' notes ...."); see also Caldwell, supra note 76 , at 5 (stating that in response to the subpoenas in his famous case, he "ripped up the notebooks... erased the tapes and shredded almost every document"). This practice raises a whole host of spoliation of evidence issues. For an overview of parties' obligations to preserve evidence (especially electronic evidence) potentially relevant in future litigation, see SEDONA CONFERENCE WORKING GROUP ON BEST Practices for Electronic Document Retention \& Production, The Sedona PRINCIPLES: BeSt PRACTICES, RECOMMENDATIONS \& PRINCIPLES FOR ADDRESSING Electronic DOCUMENT Production 11-13 (2004), available at http:// www.thesedonaconference.org/content/miscFiles/SedonaPrinciples200401.pdf. It is distressing that current judicial policy incentivizes the destruction of materials with significant potential usefulness.

${ }^{202}$ Two separate entities have tried to accomplish this daunting task. The Practicing Law Institute (PLI) publishes a comprehensive yearly guide documenting the state of the law of journalist's privilege in each state and federal circuit. Goodale et al., supra note 93. The Reporters Committee for Freedom of the Press has commissioned lawyers in each state and federal circuit to synopsize the relevant law and keep it updated in a comprehensive and easily searchable database. Reporters Comm. for Freedom of the Press, The Reporter's Privilege, http://www.rcfp.org/privilege (last visited Sept. 20, 2005).

${ }^{203}$ See Zampa, supra note 6, at 1453 (arguing that "clarity in the doctrine of privilege" is far more important than the actual level of protection, because journalists and sources will know ex ante the extent that the source's confidentiality can be protected). But cf. Vince Blasi, The Newsman's Privilege: An Empirical Study, 70 MicH. L. REV. 229, 280 (1971) (finding that journalists would prefer a statute with flexibility rather than certainty).

${ }^{204}$ See Brief of Amicus Curiae Center for Individual Freedom in Support of Petitioners at 4-5, Miller v. United States, 125 S. Ct. 2977 (2005) (No. 04-1507) ("Indeed, given the multiplicity of conflicting rulings, newsgatherers now find they enjoy dra- 


\section{The Adversarial Relationship Between the Media and Government}

The relationship between the press and the government has soured. Instead of working toward a common goal of disseminating relevant information to the public, government officials are becoming more secretive, ${ }^{205}$ which necessarily means that journalists must dig deeper to get to the root of stories. In this context, the role of confidential sources is paramount: the more tight-lipped the government, the bigger the penalty for leaking information to a reporter, ${ }^{206}$ and the more relevant that information is to the public.

In short, the press and the government view each other skeptically. ${ }^{207}$ The current Bush Administration in particular has been singled out as secretive and anti-press. ${ }^{208}$ Indeed, when Senator Dodd in-

matically different First Amendment protections for their confidential news sources from one jurisdiction to the next, from one type of case to another, and even from federal to state courts.”); Leslye DeRoos Rood \& Ann K. Grossman, The Case for a Federal Journalist's Testimonial Shield Statute, 18 HASTINGS CONST. L.Q. 779, 782 (1991) ("Uniformity of the protection afforded is essential to the free flow of information to the public."); Alger, supra note 176, at 161 ("Only an omniscient reporter could know prospectively when he or she agrees to keep a secret whether, and in what kind of proceeding, he or she will be subpoenaed.”); Jeffrey G. Sherman, Comment, Constitutional Protection for the Newsman's Work Product, 6 HARV. C.R.-C.L. L. REV. 119, 122 (1970) (noting the problem faced by "nationwide news networks who gather news in all states and are subject to subpoenas in any jurisdiction to which their operations extend"); Fargo, supra note 13, at 487 ("Journalists working on stories do not know, when they are gathering information, whether they will be subpoenaed or, if so, in what court.").

${ }_{205}$ See Rebecca Carr, Study: Feds'Secrecy Grows, Gets Costlier; Critics Say Loss of Access Hurts Public, ATLANTA J.-CONST., Sept. 4, 2005, at A3, available at 2005 WLNR 13934304 (reporting on the increase in the number of documents the federal government classifies).

${ }^{206}$ See, e.g., Jim VandeHei \& Mike Allen, Bush Raises Threshold for Firing Aides in Leak Probe, WASH. POST, July 19, 2005, at A1 (noting that President Bush stated he would fire anyone who leaked the information in the Valerie Plame case).

${ }^{207}$ See Address by William J. Brennan, Jr., supra note 23, at 174 ("[P]resent attitudes of the press toward the Supreme Court strongly suggest the complete absence of an enterprise shared by the press and the Supreme Court."); $i d$. ("I detect in the present controversy a new and disturbing note of acrimony, almost bitterness.").

${ }^{208}$ See Hertzberg, supra note 8, at 28 ("[T] he Bush Administration . . . is notoriously secretive, manipulative, and vindictive to journalists who fail to bend the knee."); Eric Boehlert, Tearing Down the Press, SALON.COM, Mar. 2, 2005, http:// www.salon.com/news/feature/2005/03/02/media/index_np.html (arguing that the Bush White House is "trying to weaken the press" because the press as "an institution [is] structurally an adversary of the White House"). But see Howard Kurtz, Is Bush Targeting the Media?, WASHINGTONPOST.COM, Mar. 3, 2005, http://www. washingtonpost.com/wp-dyn/articles/A3421-2005Mar3.html ("I would argue that nothing the [Bush] White House has done has damaged the media's credibility more than what the profession has done to itself."). 
troduced a bill to enact a federal shield law, he stated that it was necessary because " $[\mathrm{w}] \mathrm{e} .$. are entering very, very dangerous territory indeed for our democracy" due to the soured relationship between the media and the government. ${ }^{209}$

When the government respects the role of a free press in a constitutional democracy, the need for protections for journalists wanes. However, when the government seeks to control the flow of information, subpoenas journalists at increasing rates, and adopts a more adversarial stance toward the press, the need for protections for journalists waxes. ${ }^{210}$ Our country is at a point at which press freedoms are being infringed by overzealous prosecutors, and it is the role of the judiciary to come to the aid of the press and recognize a privilege for journalists.

\section{The Increasing Number of Journalists Being Held in Contempt}

When a reporter refuses a subpoena to provide testimony or submit evidence, a court has limited options: the court can excuse the reporter from compliance or hold the reporter in contempt. ${ }^{211}$ A contempt holding usually carries jail time for the reporter and a fine for her organization. ${ }^{212}$ These contempt holdings are not supposed to be retributive, though: ${ }^{213}$ the purpose in jailing a reporter is to elicit rele-

${ }^{209}$ Joseph Straw, Dodd Bill Shields Press from Reprisals, NEw HAVEN REgISTER, Nov. 20, 2004, http://www.nhregister.com (internal quotation marks omitted).

${ }^{210}$ See Sherwood, supra note 59, at 1202 (attributing the rising number of subpoenas to the more adversarial positions of the press and the government).

${ }^{211}$ When the media organization is a party to the suit, the court has more options. For instance, in one civil libel action, the court held that if the newspaper failed to identify its confidential source, then it would be presumed that no source actually existed. See DeRoburt v. Gannett Co., 507 F. Supp. 880, 887 (D. Haw. 1981) ("[W]e hold that when a defendant in a libel action, brought by a plaintiff who is required to prove actual malice under New York Times, refuses to declare his sources of information ... there shall arise a presumption that the defendant had no source." (internal quotation marks omitted) (quoting Downing v. Monitor Publ'g Co., 6 Media L. Rep. (BNA) 1193, 1195 (N.H. 1980))).

${ }^{212}$ See, e.g., In re Special Counsel Investigation, Misc. No. 04-407 (TFH) (D.D.C. Oct. 7, 2004), available at http://www.dcd.uscourts.gov/04-407.pdf (holding New York Times reporter Judith Miller in contempt for failing to provide testimony to a grand jury, and ordering her "confined to a suitable place" for no more than eighteen months), aff'd sub nom, In re Grand Jury Subpoena, Judith Miller, 397 F.3d 964, 976 (D.C. Cir. 2005), cert. denied, 125 S. Ct. 2977 (2005); Adam Liptak, Reporter from Time Is Held in Contempt in C.I.A. Leak Case, N.Y. TIMES, Aug. 10, 2004, at A1 (noting the court's decision to hold Time reporter Matthew Cooper in contempt, order him to jail, and fine the magazine $\$ 1000$ a day).

${ }^{213}$ However, Special Counsel Patrick Fitzgerald seemed to imply that he wanted reporter Judith Miller jailed, not to convince her to testify, but for punitive reasons: 
vant information from her. ${ }^{214}$ As soon as the information is no longer relevant-the reporter testifies, the case settles, the grand jury's term expires, etc.- - she is released..$^{215}$ This begs the question: If a judge is certain that a reporter will never testify, how can the judge in good conscience send her to jail?

When reporters actually do go to jail, ${ }^{216}$ it is the sad result of a game of chicken—and a clash of egos-gone terribly wrong. Judges must maintain an orderly courtroom; if a judge orders someone to provide testimony and is rebuffed, the judge-and the judiciary as a whole-is perceived as weak. The next person who does not want to accede to the judge's demands will be that much more emboldened. Therefore, the judge often follows through on her threat to jail the journalist primarily to "send a message" that her orders must be respected, no matter what the opposition. ${ }^{217}$

On the other hand, a reporter instinctively fights any effort to obtain her confidential information because she thinks that sources will stop confiding in her if word gets out that she cannot keep confidences. More generally, the reporter, not unlike the judge, wants to

“[W] e can't have 50,000 journalists' deciding when to reveal sources.” Peter Johnson \& Mark Memmott, Time Reporter to Testify; N.Y. Times Reporter Jailed, USA TODAY, July 7, 2005, at 5A, available at 2005 WLNR 10629658.

${ }^{214}$ See id. (quoting Chief Judge Hogan as stating that " $[\mathrm{t}]$ here is still a realistic possibility that confinement might cause her [Miller] to testify").

${ }_{215}$ See Carol D. Leonnig, 2 Reporters in Leak Case Given 48 Hours to Argue Against Jailing, WASH. POST, June 30, 2005, at A2 (noting that Judith Miller's jail term is set to expire when the current grand jury's term is over in October 2005).

${ }^{216}$ See Reporters Comm. for Freedom of the Press, supra note 4 (keeping an up-todate listing of reporters who were jailed over the past twenty years for refusing to testify); see, e.g., Liptak, supra note 3, at A1 (noting Judith Miller's jailing by Chief Judge Hogan for failing to provide testimony to Special Prosecutor Fitzgerald in his investigation into the disclosure of CIA agent Valerie Plame's name); Zuckerman, supra note 82 (noting that Miami Herald reporter David Kidwell spent time in jail for refusing to testify in a murder trial); AGENTS OF DISCOVERY, supra note 70, at 3 (noting one reporter's recent 168-day jail term for refusing to disclose her source). But see WRIGHT \& GRAHAM, supra note 50, \$5426, at 717 (arguing that the number of journalists who have been jailed is relatively small compared with the number of run-ins journalists have had with courts).

${ }^{217}$ However, the sentence is often light and is imposed more for appearance's sake. See WRIGHT \& GRAHAM, supra note 50, § 5426, at 717 ("Indeed, it has been suggested that the ritual jailing of reporters for short terms was a form of fiction in which journalists were granted a de facto privilege by sympathetic judges who were unwilling to diminish their own powers by the creation of a de jure privilege."). As is expected, not all commentators are satisfied with this "ritual." See, e.g., BATES, supra note 7, at 1213 (arguing that this "ritual jailing . . carries a significant cost," because "others will find it that much easier to rationalize lawlessness for venal reasons"). 
uphold the ideals of her profession and ensure that it continues to be respected. When the case reaches its climax in court, it receives great publicity, and at this point neither side wishes to be seen by the public as backing down. The judge feels compelled to follow through on her threat to jail the reporter; the reporter feels compelled to follow through on her promise never to disclose the confidential information. The result is a jailed journalist and a judge who still has not obtained the relevant information.

It is hard to determine the winner-judge or journalist-after such a confrontation. Though journalists, like most citizens, probably loathe going to jail, some treat their sentences as badges of honor and defining moments in their careers or lives, and are exalted as martyrs in the eyes of their peers and the public. ${ }^{218}$ In addition, the publicand newspapers' editorial pages-are often galvanized and roundly condemn the judiciary. ${ }^{219}$ The judiciary, on the other hand, continues to be respected by the public and feared by journalists who might encounter such a situation in the future. Respect for the rule of law lives to see another day. In the short term, though, a journalist sits in jail and a judge is left without the necessary evidence. Both sides lose.

${ }^{218}$ See Ervin, supra note 148, at 257 (noting that when "martyred newsmen" went to jail for refusing to disclose their source, the issue was dramatized and the public generally came to their support); see, e.g., TORRE, supra note 98 (chronicling her own rise to fame and the unending support from fellow journalists after her legal dispute); Howard Kurtz, Contempt E Praise for Reporter, WASH. Post, Feb. 17, 2005, at C1 (quoting an editor of the Columbia Journalism Review as saying that a certain reporter facing jail time for refusing to disclose her source was "being cast in the role of journalistic martyr" (internal quotation marks omitted)); $i d$. (quoting an editor of the National Review as stating that by accepting jail time for refusing to disclose her source, a reporter "helps burnish her credentials, and deservedly so, as a serious journalist who's sticking up for her principles" (internal quotation marks omitted)). But see Carol D. Leonnig, Time Reporter's Testimony Sought: Prosecutor Tries to Force Cooperation, WASH. POST, July 6, 2005, at A3 (quoting Special Counsel Fitzgerald as calling Judith Miller's refusal to testify "irresponsible martyrdom" (internal quotation marks omitted)).

${ }^{219}$ See, e.g., Op-Ed, Attack on a Free Press, S.F. Chron., July 7, 2005, at B8 ("By jailing New York Times reporter Judith Miller, federal judges and prosecutors have sent a chilling message to all journalists and Americans: Freedom of the press and the public's right to know are under attack."); Editorial, If the Next Deep Throat Clams Up, OREGONIAN, July 1, 2005, at E6, available at 2005 WLNR 10441643 ("Democracy . . . is in trouble.... [Citizens] can't afford a free press that's only free enough to write stories of no consequence."); Nicholas D. Kristof, Editorial, Our Not-So-Free Press, N.Y. TIMES, Nov. 10, 2004, at A25 (equating the United States to China and Zimbabwe for "throwing journalists in prison"); Editorial, Press Imprisoned: Jailing Reporter Is No Way To Achieve Justice, PitTsburgh Post-GAZETTe, July 9, 2005, at B6 ("The imprisonment of Judith Miller is shameful.... [T] he principal casualty so far in the whole case is America's press freedom.”). 
A journalist's privilege would prevent—or at least mitigate-such a sad conclusion to the conflict between two professionals both attempting to uphold the integrity of their profession.

\section{JUdicial ANTAgOnism TOWARd A JOURnalist's PRIVILEge}

\section{A. Why Judges Are Traditionally Opposed to the Idea}

Judges are typically opposed to privileges-all privileges-because they hinder the search for truth. ${ }^{220}$ This Part explores some examples of the judiciary's difficulty with a potential press privilege. ${ }^{221}$

While thirty-two states have shield laws, ${ }^{222}$ reflecting the wishes of the legislative branch, judges in many of those states have narrowed the application of those laws. ${ }^{223}$ In Florida, for example, a court held that the shield law did not apply to eyewitness observations or physical evidence of a crime, and instituted a four-part, testimony-friendly test for overcoming the privilege in criminal cases. ${ }^{24}$

${ }^{220}$ See United States v. Nixon, 418 U.S. 683, 710 (1974) (“[E]xceptions to the demand for every man's evidence are not lightly created nor expansively construed, for they are in derogation of the search for truth."); In re Dinnan, 661 F.2d 426, 430 (5th Cir. Unit B Nov. 1981) ("[T] here has been a notable hostility on the part of the judiciary to recognizing new privileges." (citing MCCORMICK, HANDBOOK ON THE LAW OF EVIDENCE $§ 77$ (2d ed. 1972))); Robertson v. Neuromedical Ctr., 169 F.R.D. 80, 83 (M.D. La. 1996) (“[P] rivileges are strongly disfavored in federal practice . ...”); Fargo, supra note 13, at 189 ("Privileges generally are suspect to legal authorities because they are counter-intuitive in a system designed to arrive at the truth."); see also CHRISTOPHER B. Mueller \& LAIRD C. KirkPATRICK, EvidenCE Under THE Rules: TeXt, CASES, AND Problems 757 (5th ed. 2004) ("[Privileges] are intended to protect certain societal relationships and values, even though such protection may impose significant costs upon the litigation process. Their effect in any given trial may be to impede the search for the truth.").

${ }^{221}$ Non-legal arguments against recognition of a privilege for journalists include journalists' tendency to sensationalize, the belief that no one is "above the law," the definitional problem of deciding who qualifies as a journalist, and the possibility that a privilege would give journalists too much (undeserved) power in our society. For an overview of these arguments, see Karl H. Schmid, Journalist's Privilege in Criminal Proceedings: An Analysis of United States Courts of Appeals' Decisions from 1973 to 1999, 39 AM. CRIM. L. REV. 1441, 1458-60 (2002).

${ }^{222}$ See supra note 120 (listing the states' statutes).

${ }^{223}$ See VAN GERPEN, supra note 6, at 145 ("Judges often narrow the application of statutes beyond what appears to have been the intent of the legislature."); WRIGHT \& GRAHAM, supra note 50, $\$ 5426$, at 734 (noting that significant judicial hostility to the idea has led to the narrowing of many of the shield laws).

${ }^{224}$ See Florida v. Davis, 720 So. 2d 220, 225 (Fla. 1998) ("The privilege not to disclose relevant evidence obviously constitutes an extraordinary exception to the general duty to testify." (quoting Miami Herald Publ'g. Co. v. Morejon, 561 So. 2d 577, 581 
In addition, some judges may be opposed to a press privilege because of what they see as a deterioration of news coverage. In today's world of twenty-four-hour cable news networks, competition has forced many media outlets to sensationalize their coverage of events, especially of trials. Judges' reactions to these "media circuses" ${ }^{225}$ may be to curtail some of the privileges normally afforded the press. ${ }^{226}$

Some commentators ascribe to the courts a perfectly legitimate jurisprudential reason for not being receptive to a press privilege. For example, Professor Anthony Fargo explains that courts are reluctant to grant journalists special privileges because, under current Supreme Court jurisprudence, if the media were granted special access rights or privileges to disregard subpoenas, then every person would have to have the same rights. ${ }^{227}$ This would in effect destroy some other vital press protections.

Finally, the debate over press privileges might be considered one between two institutions, each of which thinks it is best suited to represent the interests of the people. The judiciary has long held itself out as protecting the best interests of society, especially through its adjudicative procedures. The press has also long claimed to represent

(Fla. 1990) (internal quotation marks omitted))); Laurence B. Alexander \& Anthony L. Fargo, Sources of Protection: A Case Study of the Evolution of the Common Law and Statutory Journalist's Privilege, 37 FREE SPEECH Y.B. 17, 34 (1999) (describing Florida's fourprong test and why it limits the scope of the privilege).

${ }^{225}$ See JON BRUSCHKE \& William E. LOGES, FrEE Press vs. FAIR TRIALS: EXAMINING PUblicity's Role IN TRIAL OUTCOMES 1 (2004) ("The media circus that appears at so many trials these days needs a ringmaster to balance the rights of the media and the accused." (quoting J.A. Walton, From O.J. to Tim McVeigh and Beyond: The Supreme Court's Totality of Circumstances Test as Ringmaster in the Expanding Media Circus, 75 DENV. U. L. REV. 549, 588 (1998))).

${ }^{226}$ See Fargo, supra note 13, at 22 ("[J] udges have become less sympathetic to the press, in part because of what they see as sensational trial coverage." (citing HOLLI HARTMAN, SOC'Y OF PROF'L JOURNALISTS, THE EROSION OF THE REPORTER'S PRIVILEGE 4-5, $9(1997)))$. This charge against the press is not new. Professor Christopher Tiedman wrote in 1886 that the press had too much power and tended to publish "sensational, and oftener false, accounts of individual wrongs and immoralities." CHRISTOPher G. Tiedman, A Treatise on the Limitations of the Police Power in the UNITED STATES 190 (Lawbook Exchange 2001) (1886).

${ }^{227}$ See Fargo, supra note 13, at 163 ("If the media have special access rights to places and information or a privilege not to reveal information when faced with a properly issued subpoena, then everyone does."). Fargo notes that Supreme Court jurisprudence has its upsides for the press, too: "if town gossips could not be gagged, neither could the press." Id. at 175 . 
"the people." The clash between these two institutions may therefore be seen as a battle for power. ${ }^{228}$

\section{B. The Supreme Court's Specific Opposition in Branzburg}

The Court's opinion in Branzburg demanded empirical evidence of the "chilling effect" journalists. ${ }^{230}$ This demand was without merit and epitomized the Court's antagonism toward the idea of press privileges. In contrast, the Supreme Court in several other cases has accepted at face value the premise that certain governmental actions would unnecessarily chill important First Amendment rights. ${ }^{231}$

In addition, assuming arguendo that the Court requires proof of the chilling effect, today that proof exists. Only two years after the Court decided against a privilege in Branzburg, it found an executive privilege in United States $v$. Nixon. ${ }^{232}$ The irony is that the Court readily accepted the idea that necessary communications between the President and his advisors would be unduly chilled without such a privi-

${ }^{228}$ See Allen, supra note 20, at 49 (arguing that the debate over a journalist's privilege "is really a battle over which institution-the courts or the press-is best qualified to be the public's representative").

${ }^{229}$ Some commentators note that the "chilling effect" can cut both ways. See, e.g., BATES, supra note 7, at 12 (arguing that because of the press's unique power to make its "screams of pain heard," prosecutors are reluctant to pressure the press too hard or too often with subpoenas, and are therefore "chill[ed]" in their investigatory efforts (quoting Michael Kinsley, The Press Doesn't Own the First Amendment, in MEDIA VOICES: DEBATING CRITICAL IsSUES IN MASS MEDiA 148 (George McKenna ed., 1982))).

${ }^{230}$ See Branzburg v. Hayes, 408 U.S. 665, 693-94 (1972) (claiming that "the evidence fails to demonstrate that there would be a significant constriction of the flow of news to the public if this Court reaffirms the prior common-law and constitutional rule regarding the testimonial obligations of newsmen," and further emphasizing the speculative nature of the effectiveness of subpoenas).

${ }^{231}$ See, e.g., Jaffee v. Redmond, 518 U.S. 1, 11-12 (1996) ("If the privilege were rejected, confidential conversations between psychotherapists and their patients would surely be chilled."); Freedman v. Maryland, 380 U.S. 51, 61 (1965) (holding that a Maryland law requiring motion pictures to be shown to the state before being exhibited to the public had a "potentially chilling effect" on free speech); Shelton v. Tucker, 364 U.S. 479, 487 (1960) (holding that a state statute requiring prospective public school teachers to disclose their associational ties had a "tendency to chill" teachers' freedom of expression and association); Smith v. California, 361 U.S. 147, 153-54 (1959) (requiring no evidence to support its conclusion that a bookseller would be chilled from selling books if he could be criminally liable for possession of obscene books).

${ }^{232} 418$ U.S. 683,708 (1974); see SMOLLA, supra note 159, § 25:21, at 38 n.5 (noting that the Court in Nixon found deterrence "not by reason of empirical evidence, but rather because of what 'human experience teaches'”). 
lege. The Court failed to show the same deference in Branzburg to the "human experience" that explains why confidential sources are less likely to divulge information to journalists if the journalists can be forced to identify the source.

Further supporting his position denying a press privilege, Justice White expressed the fear in Branzburg that if the definition of "newsman" was too broad, criminal groups could set up "sham" newspapers in order to shield themselves from grand jury inquiry. ${ }^{233}$ The authors of an influential treatise on federal practice mock this idea: "Perhaps in law school examinations one finds criminals who publish accounts of their misdeeds in order to claim the newsmen's privilege when called to testify before the grand jury," but despite exhaustive research, the authors "failed to turn up a single instance that even remotely resembles the hypothesis." ${ }^{234}$ It is ironic that Justice White based his opposition to a journalist's privilege on a lack of empirical evidence regarding the chilling of the press and yet relied on this farfetched hypothetical without any empirical support.

In short, the Court's insistence in Branzburg on solid empirical evidence was without merit. ${ }^{235}$ Further, even if empirical evidence is needed to convince the Court that speech is chilled without a privilege, that evidence is now available. The Supreme Court was not content in Branzburg to rely on Professor Blasi's comprehensive study. ${ }^{236}$

${ }^{233} 408$ U.S. at 705 n.40. Judge Sentelle offers his own version, updated since Branzburg's time, of a hypothetical that would threaten to swallow the whole privilege:

[W] ould it not be possible for a government official wishing to engage in the sort of unlawful leaking under investigation in the present controversy to call a trusted friend or a political ally, advise him to set up a web log (which I understand takes about three minutes) and then leak to him under a promise of confidentiality the information which the law forbids the official to disclose? In re Grand Jury Subpoena, Judith Miller, 397 F.3d 964, 979-80 (D.C. Cir.) (Sentelle, J., concurring), cert. denied, 125 S. Ct. 2977 (2005).

${ }^{234}$ WRIGHT \& GRAHAM, supra note $50, \S 5426$, at 753 \& n.21.

${ }^{235}$ See Branzburg, 408 U.S. at 733 (Stewart, J., dissenting) (“[W]e have never before demanded that First Amendment rights rest on elaborate empirical studies demonstrating beyond any conceivable doubt that deterrent effects exist...."); Neubauer, supra note 156, at 173-74 (arguing that the "Branzburg majority relied too heavily on a quantitative rather than a qualitative analysis," given that the most important types of stories are precisely those that require a privilege for journalists).

${ }^{236}$ See 408 U.S. at 694 (refusing to give weight to Blasi's study because "surveys of reporters on this topic are chiefly opinions of predicted informant behavior and must be viewed in the light of the professional self-interest of the interviewees"). Blasi's study, cited in Branzburg as a paper entitled "Press Subpoenas: An Empirical and Legal Analysis, Study Report of the Reporters' Committee on Freedom of the Press," $i d$. at 694 n.33, was later published as "The Newsman's Privilege: An Empirical Study" in the Michigan Law Review. Blasi, supra note 209. 
But two studies since then, one by Boston lawyer John Osborn ${ }^{237}$ and one by Professor Laurence Alexander, ${ }^{238}$ have shown that news informants are dissuaded from divulging information to reporters, and that reporters are less likely to pursue such stories, if there is not a high degree of certainty that the confidentiality cannot be pierced.

Regardless of the empirical findings, the fact remains that proving a "chilling effect" is an elusive task, and one that the Supreme Court has not required in other First Amendment contexts. A privilege for journalists should receive the same treatment from the Court.

\section{The Supreme Court Should Recognize a Journalist's Privilege GROUNDED IN THE COMMON LAW}

In light of the actions and statements of lower courts, commentators, foreign courts, state legislatures, and Congress, the Supreme Court should recognize a journalist's privilege under Federal Rule of Evidence $501 .^{239}$

Rule 501 refers to the "principles of the common law as they may be interpreted by the courts of the United States." ${ }^{240}$ The common law is a changing, evolving concept, and the framers of the Federal Rules of Evidence wanted the rules to have the flexibility to adapt with the times. ${ }^{241}$ Congress specifically rejected the Supreme Court's pro-

${ }^{237}$ Osborn, supra note 194.

${ }^{238}$ Alexander et al., supra note 174.

${ }^{239}$ FED. R. EVID. 501 provides in relevant part:

Except as otherwise required by the Constitution of the United States or provided by Act of Congress or in rules prescribed by the Supreme Court pursuant to statutory authority, the privilege of a witness . . . shall be governed by the principles of the common law as they may be interpreted by the courts of the United States in the light of reason and experience.

For an interpretation of Congress's possible intentions in enacting Rule 501, see Edward J. Imwinkelried, An Hegelian Approach to Privileges Under Federal Rule of Evidence 501: The Restrictive Thesis, the Expansive Antithesis, and the Contextual Synthesis, 73 NEB. L. REV. 511, 517-23 (1994).

${ }^{240}$ FED. R. EVID. 501; cf. 28 U.S.C. § 2254(d) (1) (2000) (providing that in habeas corpus proceedings, courts should look only to precedent as established by the Supreme Court, and not to other courts' interpretations).

${ }^{241}$ See Jaffee v. Redmond, 518 U.S. 1, 8-9 (1996) ("Rule [501] thus did not freeze the law governing the privileges of witnesses in federal trials at a particular point in our history, but rather directed federal courts to "continue the evolutionary development of testimonial privileges." (quoting Trammel v. United States, 445 U.S. 40, 47 (1980))); WRIGHT \& GRAHAM, supra note 50, § 5426, at 712 n.4 (quoting Congressman Hungate as saying that " $[\mathrm{t}]$ he language of Rule 501 permits the courts to develop a privilege for 
posed rule regarding privileges (which would have created nine specific privileges) ${ }^{242}$ and instead implemented this flexible rule. ${ }^{243}$

The Supreme Court interpreted Rule 501 in Jaffee v. Redmond when it recognized a privilege for psychotherapist-patient communications. ${ }^{244}$ The Court looked to the states for guidance on the issue, and used the fact that all fifty states recognized the privilege as support for its own conclusion. ${ }^{245}$ Support for the privilege was not as strong in the federal courts; while two circuit courts explicitly recognized the privilege, four circuit courts explicitly declined to do so. ${ }^{246}$ The Court also reasoned that if it failed to grant the privilege, the intentions of the state legislatures would be frustrated. ${ }^{247}$ Finally, the Court relied on the fact that a psychotherapist-patient privilege was

newspaper-people on a case-by-case basis," consistent with the principles of the common law (citing 120 CONG. REC. 40890, 40891 (1974) (statement of Rep. Hungate))).

${ }^{242}$ See Proposed Federal Rules of Evidence 501-510, 56 F.R.D. 183, 230-58 (1972) (proposing to protect (1) certain reports required by statute, (2) attorney-client communications, (3) psychotherapist-patient communications, (4) husband-wife communications, (5) clergyman-penitent communications, (6) political votes, (7) trade secrets, (8) state secrets, and (9) government-informer communications).

${ }^{243}$ FED. R. EvID. 501; see also Theodore J. Boutrous, Jr. \& Seth M.M. Stodder, Retooling the Federal Common-Law Reporter's Privilege, Comm. LAw., Spring 1999, at 1, 25 ("The legislative history of Rule 501 manifests that its flexible language was designed to encompass, inter alia, a reporter's privilege not to disclose a source." (quoting Riley v. City of Chester, 612 F.2d 708, 714 (3rd Cir. 1979) (internal quotation marks omitted))); Imwinkelried, supra note 239, at 542 ("Congress did not freeze federal privilege law. Rule 501 does not preclude the recognition of novel privileges ....").

${ }^{244} 518$ U.S. 1, 15 (1996). The decision, however, was not unanimous, and Justice Scalia wrote in dissent that the Court had failed to be the guardian of the judiciary's truth-seeking mission: "There is no self-interested organization out there devoted to pursuit of the truth in the federal courts. The expectation is, however, that this Court will have that interest prominently-indeed, primarily-in mind. Today we have failed that expectation, and that responsibility." Id. at 36 (Scalia, J., dissenting).

245 See $i d$. at 12 ("That it is appropriate for the federal courts to recognize a psychotherapist privilege under Rule 501 is confirmed by the fact that all 50 States and the District of Columbia have enacted into law some form of psychotherapist privilege."); see also Atkins v. Virginia, 536 U.S. 304, 314-17 (2002) (noting that the fact that thirtyone states have laws prohibiting the banned practice of executing mentally retarded offenders "reflects widespread judgment" among the states).

${ }^{246}$ See Jaffee, 518 U.S. at 7 (listing the stances of the courts of appeals that had considered the issue).

${ }^{247}$ Id. at 13. The Court elaborated:

[G]iven the importance of the patient's understanding that her communications with her therapist will not be publicly disclosed, any State's promise of confidentiality would have little value if the patient were aware that the privilege would not be honored in a federal court. Denial of the federal privilege therefore would frustrate the purposes of the state legislation that was enacted to foster these confidential communications.

Id. 
among the nine proposed privileges of the Judicial Conference Advisory Committee (which were rejected by Congress in favor of the current open-ended Rule 501). ${ }^{248}$

The parallels between the support for a journalist's privilege and a psychotherapist-patient privilege are apparent: almost all states recognize the journalist's privilege ${ }^{249}$ and most federal courts of appeals recognize it. ${ }^{250}$ Furthermore, the lack of a journalist's privilege at the federal level frustrates the interests of more than thirty state legislatures and several more state supreme courts, all of which have recognized the important societal interest in protecting journalists' sources. ${ }^{251}$ As was the case in Jaffee, "any State's promise of confidentiality would have little value if the patient"-here, substitute "confidential news source"-"were aware that the privilege would not be honored in a federal court." 252 The Court plugged the loophole that allowed the confidential information to be attained simply by changing the forum (i.e., by bringing suit in federal court). ${ }^{253}$ Finally, the public interests served by the journalist's privilege-an informed citizenry and a check on government abuse-far outweigh the more limited and personal interests served by the psychotherapist-patient privilege. ${ }^{254}$

${ }^{248}$ Id. at 14-15; see also Proposed Federal Rules of Evidence 501-510, 56 F.R.D. 183, 230-58 (1972) (proposing to protect psychotherapist-patient communications). A journalist's privilege was not included in that original list of nine. $I d$.

${ }^{249}$ For purposes of consensus on the issue, it is of little consequence that the state shield laws differ in their scope. See, e.g., Jaffee, 518 U.S. at 14 n.13 ("These variations in the scope of the protection are too limited to undermine the force of the States' unanimous judgment that some form of psychotherapist privilege is appropriate.").

${ }^{250}$ Nine circuits have explicitly recognized a journalist's privilege. See supra notes 103-111 and accompanying text (listing and discussing the cases). In comparison, only two circuits recognized the psychotherapist-patient privilege pre-Jaffee. See 518 U.S. at 7 (listing the courts).

${ }^{251}$ Indeed, the attorneys general of thirty-four states filed an amicus brief asking the Supreme Court to recognize a federal reporter's privilege, arguing that the absence of federal protection undermines the intent of the states. See Brief Amici Curiae of the States of Oklahoma et al. in Support of Petitioners at 3-5, Miller v. United States, 125 S. Ct. 1977 (2005) (No. 04-1507), available at http://www.cfac.org/Attachments/ State_AG_brief_Plame.pdf ("The lack of a corresponding federal reporter's privilege undermines these vital state interests [in promoting a free society and an informed citizenry].").

${ }_{252}^{252}$ Jaffee, 518 U.S. at 13.

${ }^{253}$ This is more applicable to civil suits; the forum for criminal prosecutions is, of course, more fixed.

${ }^{254}$ See Boutrous \& Stodder, supra note 243, at 23 ("[W]hile the psychotherapistpatient's privilege serves 'the mental health of our citizenry,' ... the reporter's privilege serves the health of our democracy ....”). 
One case study from Florida highlights the positive effect that the passage of a shield law had on the press and judiciary in the state. ${ }^{255}$ The authors of the case study analyze the state of the case law prior to the statutory enactment of a journalist's privilege law and argue that reporters-and lawyers and judges-were "confus[ed] about the extent of the journalist's privilege" due to "contradictory appellate court rulings. ${ }^{256}$ The new law-and the state supreme court's pronouncement on that law-has made journalists more certain about their legal standing when engaging in certain activities and has helped alleviate needless subpoena confrontations and jailing of reporters. ${ }^{257}$ The researchers' findings can be extrapolated to the national stage: because of contradictory appellate court rulings and confusion over when a state shield law applies, journalists—and lawyers and judges-are unsure of the legal status of privilege claims. This leads to worse journalism and needless confrontations between the press and the judiciary. If society is to have any hope of restoring the relationship between the press and the judiciary, a greater degree of certainty is required.

Since Branzburg was decided, commentators have recognized that lower courts are without guidance on the issue of a journalist's privilege and have called for the Supreme Court to make a more precise pronouncement. ${ }^{258}$ Most commentators are in agreement that the courts, because they are closer to the issue, are better suited to make a decision than is Congress. ${ }^{259}$ Indeed, Congress, in promulgating Rule 501 , basically asked the courts to be the arbiters of privileges. ${ }^{260}$

${ }^{255}$ Alexander \& Fargo, supra note 224, at 35.

${ }^{256} I d$.

${ }^{257} \mathrm{Id}$.

${ }^{258}$ See In re Grand Jury Subpoena, Judith Miller, 405 F.3d 17, 18 (D.C. Cir.) (en banc) (Tatel, J., concurring) ("Only the Supreme Court can limit or distinguish Branzburg on [facts similar to a reporter refusing to identify a confidential source to a grand jury].”), cert. denied, 125 S. Ct. 2977 (2005); In re Grand Jury Subpoena, Judith Miller, 397 F.3d 964, 979 (D.C. Cir.) (Sentelle, J., concurring) ("I think it remains the prerogative of the Supreme Court rather than inferior federal tribunals to determine whether these changes are sufficient to warrant an overruling of the Court's rejection of such a common law privilege in Branzburg."), cert. denied, 125 S. Ct. 2977 (2005); see also George M. Killenberg, Branzburg Revisited: The Struggle to Define Newsman's Privilege Goes On, 55 JOURN. Q. 703, 710 (1978) ("[I]n absence of a more precise decision by the United States Supreme Court, the boundaries of newsmen's privilege will continue to be drawn case by case in the lower courts by ad hoc balancing.").

${ }^{259}$ See Raymond F. Miller, Comment, Creating Evidentiary Privileges: An Argument for the Judicial Approach, 31 CoNN. L. REV. 771, 771 (1999) (arguing for judicial, rather than legislative, recognition of evidentiary privileges); see also Ervin, supra note 148, at 277-78 (concluding that judicial enforcement of the First Amendment, rather than federal legislation, might be the soundest recourse to protect the press's freedom); Sherwood, supra note 59, at 1250 ("Newsman's privilege is a constitutional issue; one 
The common law represents the development of an understanding among the courts about the current state of the law. As is traditional for evidentiary issues, the understanding of the common law "bubbles up" from the bottom, from the courts that are presented with the issue most often. Over time, this mass of lower court decisions percolates upward. Then the Supreme Court is given the opportunity to comment on the state of the law in the lower courts, and, more importantly, to provide them guidance so that the law can develop uniformly in the various jurisdictions.

The time has come for the Supreme Court to take this step in the area of journalist's privilege law. Thirty-two states have recognized the privilege by statute, ${ }^{261}$ and eighteen more by judicial means. Nine of the circuits have also explicitly recognized the privilege. ${ }^{262}$ Legislators continue to introduce legislation, and Congress continues to consider enacting federal protections. One commentator (an Assistant U.S. Attorney), who is firmly opposed to a journalist's privilege for nonconfidential information, ${ }^{263}$ freely admits that the "federal common law

that belongs in the courts.”). But see Rood \& Grossman, supra note 204, at 782 (arguing that it is important that a reporter's privilege at the federal level be developed by the legislature, and not the judiciary, because "the creation of testimonial privilege entails the weighing of competing policy interests, which is a legislative and not a judicial function"). Rood and Grossman give three reasons why the legislature must craft the law: first, the judiciary must remain independent from the "influences of the political fray;" second, separation of powers would be maintained; and third, a statute would provide for more uniformity and clarity than a judicially created rule. $I d$.

${ }^{260}$ See Imwinkelried, supra note 239, at 530-35 (showing that Congress, in enacting Rule 501, reached a "political compromise," and therefore did not provide any useful guidance to the courts on whether they should be receptive or hostile to privilege claims).

${ }^{261}$ Whether a state recognizes the privilege legislatively or judicially is irrelevant. See Jaffee v. Redmond, 518 U.S. 1, 13 (1996) ("It is of no consequence that recognition of the privilege in the vast majority of States is the product of legislative action rather than judicial decision. Although common-law rulings may once have been the primary source of new developments in federal privilege law, that is no longer the case.").

${ }^{262}$ Indeed, since almost immediately after Branzburg was handed down, lower courts have been finding the privilege in various circumstances. See, e.g., Silkwood v. Kerr-McGee Corp., 563 F.2d 433, 437 (10th Cir. 1977) (declaring, only five years after Branzburg, that the existence of a press "privilege is no longer in doubt"). Some of the courts of appeals have even explicitly recognized the journalist's privilege in the common law, as provided in Rule 501. See, e.g., United States v. Cuthbertson, 630 F.2d 139, 146 (3d Cir. 1980) ("[J]ournalists have a federal common-law qualified privilege arising under Fed. R. Evid. 501 to refuse to divulge their confidential sources.").

${ }^{263}$ See Christopher J. Clark, The Recognition of a Qualified Privilege for Non-Confidential Journalistic Materials: Good Intentions, Bad Law, 65 BROOK. L. REV. 369, $377-79$ (1999) (criticizing the authors of Gonzales v. Nat'l Broad. Co., 186 F.3d 102 (2d Cir. 1998), 
provides ... a qualified privilege" for confidential materials. ${ }^{264}$ Indeed, Judge Tatel, though voting to affirm the contempt citations of two prominent reporters, declared: "I believe that the consensus of forty-nine states plus the District of Columbia-and even the Department of Justice-would require us to protect reporters' sources as a matter of federal common law ...."

\section{CONCLUSION}

The case for a journalist's privilege has been significantly strengthened since Branzburg was decided over thirty years ago, and the time has come for the Supreme Court to recognize this important privilege as part of the common law. The interests of the press have been neglected (at the unneeded expense of government) for too long. As Thomas Jefferson famously wrote:

The basis of our government[] being the opinion of the people, the very first object should be to keep that right; and were it left to me to decide whether we should have a government without newspapers, or newspapers without a government, I should not hesitate a moment to prefer the latter. $^{266}$

The Supreme Court should not hesitate a moment in performing this vital task.

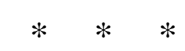

\section{POSTSCRIPT}

Judith Miller was released from jail on September 29, 2005, ${ }^{267}$ shortly after this Comment went to press. After being personally assured by her confidential source, Vice President Cheney's Chief of

which granted equal protection for journalists' confidential and nonconfidential materials, for making "bad law").

${ }^{264} I d$. at 377 . The state of the common law in this area has certainly changed since Branzburg's time. See Brewster v. Boston Herald-Traveler Corp., 20 F.R.D. 416, 417 (D. Mass. 1957) (denying the privilege on common law grounds); Guest \& Stanzler, supra note 17 , at 56 ("[C] ourts are not going to find a newsman's privilege under the common law.").

${ }^{265}$ In re Grand Jury Subpoena, Judith Miller, 397 F.3d 964, 986-87 (D.C. Cir.) (Tatel, J., concurring), cert. denied, 125 S. Ct. 2977 (2005).

${ }^{266}$ Letter from Thomas Jefferson to Edward Carrington (Jan. 16, 1787), in 11 THE PAPERS OF THOMAS JEFFERSON, 1 JANUARY TO 6 August 1787, at 49 (Julian P. Boyd ed., 1955).

267 David Johnston \& Douglas Jehl, Times Reporter Free From Jail; She Will Testify, N.Y. TIMES, Sept. 30, 2005, at A1. 
Staff I. Lewis Libby, that her silence on the issue was no longer necessary, Miller struck a deal with Special Counsel Patrick Fitzgerald to provide limited testimony to the federal grand jury investigating the Valerie Plame leak. ${ }^{268}$ Miller apparently spent over twelve weeks in jail in part because her and her lawyers were unsure of the sincerity of Lewis's "waiver" of confidentiality. ${ }^{269}$

As of this writing, the extent of Miller's testimony and the impact it will have on Fitzgerald's investigation remain unclear. However, the lesson that can be drawn from this saga is clear: a reporter spent three months in jail because she, her sources, her lawyers, a federal prosecutor, a district judge, and the D.C. Circuit could not come to a conclusion about whether a journalist's privilege exists in the common law. The Supreme Court urgently needs to clarify the law in this area.

${ }^{268} I d$.

269 For a demonstration of the confusion among Miller, her lawyer, Libby, his lawyer, and Fitzgerald about whether a waiver was offered, whether that waiver was voluntary, when such a waiver was offered, and when that offer was communicated to Miller, see Letter from I. Lewis Libby, Chief of Staff, Vice President Cheney, to Judith Miller, Reporter, New York Times (Sept. 15, 2005), Letter from Joseph A. Tate, Partner, Dechert LLP, to Patrick J. Fitzgerald, Special Counsel (Sept. 16, 2005), and Letter from Floyd Abrams, Partner, Cahill Gordon \& Reindel LLP, to Joseph A. Tate, Partner, Dechert LLP (Sept. 29, 2005), available at http://www.nytimes.com/packages/pdf/ national/nat_MILLER_051001.pdf. 